Georgetown University Law Center

Scholarship @ GEORGETOWN LAW

2020

\title{
Discounting Credibility: Doubting the Stories of Women Survivors of Sexual Harassment
}

Deborah Epstein

Georgetown University Law Center, epstein@law.georgetown.edu

This paper can be downloaded free of charge from:

https://scholarship.law.georgetown.edu/facpub/2253

https://ssrn.com/abstract=3575843

Seton Hall Law Review, Vol. 51, Issue 2, Pp. 289-329.

This open-access article is brought to you by the Georgetown Law Library. Posted with permission of the author. Follow this and additional works at: https://scholarship.law.georgetown.edu/facpub

Part of the Civil Rights and Discrimination Commons, Labor and Employment Law Commons, Law and Gender Commons, and the Law and Psychology Commons 


\title{
Discounting Credibility: Doubting the Stories of Women Survivors of Sexual Harassment
}

\begin{abstract}
Deborah Epstein*
For decades, federal and state laws have prohibited sexual harassment on the job; despite this fact, extraordinarily high rates of gender-based workplace harassment still permeate virtually every sector of the American workforce. Public awareness of the seriousness and scope of the problem increased astronomically in the wake of the \#MeToo movement, as women began to publicly share countless stories of harassment and abuse. In 2015, the Equal Employment Opportunity Commission's Task Force on the Study of Harassment in the Workplace published an important study analyzing a wide range of factors contributing to this phenomenon. But the study devotes only limited attention to a factor that goes straight to the heart of the problem: our reflexive inclination to discount the credibility of women, especially when those women are recounting experiences of abuse perpetrated by more powerful men. We will not succeed in ending gender-based workplace discrimination until we can understand and resist this tendency and begin to appropriately credit survivors' stories.

How does gender-based credibility discounting operate? First, those charged with responding to workplace harassment-managers, supervisors, union representatives, human resource officers, and judgesimproperly discount as implausible women's stories of harassment due to a failure to understand either the psychological trauma caused by abusive treatment or the practical realities that constrain women's options in its aftermath. Second, gatekeepers unjustly discount women's personal trustworthiness, based on their demeanor (as affected by the trauma they often have suffered); on negative cultural stereotypes about women's motives for seeking redress for harms; and on our deep-rooted cultural belief that women as a group are inherently less than fully trustworthy.
\end{abstract}

${ }^{*}$ Professor and Co-director of the Domestic Violence Clinic, Georgetown University Law Center. I am deeply indebted, in this as in so many of my professional endeavors, to Lisa Goodman, my longtime partner in investigating and conceptualizing issues centered on violence against women. I would also like to thank Anna Harty, Nadia Finkel, and Elana Orbuch for their valuable research assistance. 
The impact of such unjust and discriminatory treatment of women survivors of workplace harassment is exacerbated by the larger "credibility economy"-the credibility discounts imposed on many women-victims can only be fully understood in the context of the credibility inflations afforded to many male harassers. Moreover, discounting women's credibility results in a particular and virulent set of harms, which can be measured as both an additional psychic injury to survivors, and as an institutional betrayal that echoes the harm initially inflicted by harassers themselves.

It is time-long past time-to adopt practical, concrete reforms to combat the widespread, automatic tendency to discount women and the stories they tell. We must embark on a path toward allowing women who share their experiences of male abuses of workplace power to trust the responsiveness of their employers, judges, and our larger society.

I. INTRODUCTION

II. CREDIBILITY DisCOUNTS BASED ON STORY PlaUSIBILITY

A. The Plausibility of Women's Stories of Workplace Harassment 295

1. Women Who Don't Report, or Don't Report Immediately 299

2. Women Who Remain on the Job 303

III. CREDIBILITY DisCountS BASED ON STORYTELLER TRUSTWORTHINESS... 305

A. Survivor Demeanor 305

B. Survivor Motive 307

C. Survivors as Women 311

IV. Credibility Inflation Awarded to Male Perpetrators of Sexual HARASSMENT . 316

V. THE IMPACT OF CREDibILITY DisCOUNTS ON WOMEN SuRvivorS OF WORKPLACE HARASSMENT 319

VI. MOVING ForWARD: INITIAL STEPS TOWARD ERADICATING GENDER-BASED CREDIBILITY DisCOUNTING IN THE WORKPLACE HARASSMENT CONTEXT

VII. CONCLUSION 329 


\section{INTRODUCTION}

Long after federal law prohibited sexual harassment on the job, extraordinarily high rates of gender-based workplace harassment still permeate virtually every sector of the American workforce. ${ }^{1}$ Public awareness of the seriousness and scope of the problem increased astronomically in the wake of the \#MeToo movement, as women began to publicly share countless stories of harassment and abuse. ${ }^{2}$

Surveys show that a substantial majority of working women experience gender-based, discriminatory harassment at work. ${ }^{3}$ Such harassment includes a wide range of behaviors, including sexual

1 Jocelyn Frye, Not Just the Rich and Famous: The Pervasiveness of Sexual Harassment Across Industries Affects All Workers, CTR. For AM. Progress (Nov. 20, 2017, 4:59 PM), https://www.americanprogress.org/issues/women/news/2017/11/20/443139/notjust-rich-famous/.

2 Emma Brockes, \#MeToo Founder Tarana Burke: 'You Have to Use Your Privilege to Serve Other People,' GuARDIAN (Jan. 15, 2018, 23:57 AM), https://www.theguardian.com/ world/2018/jan/15/me-too-founder-tarana-burke-women-sexual-assault. The movement, which exploded in scope in the fall of 2017, grew out of a phrase used twelve years earlier by social activist Tarana Burke, whose work focused on abuse experienced by women of color. $I d$.

3 See, e.g., ABC News/Wash. Post Poll: Sexual Harassment (Oct. 17, 2017), https://www.langerresearch.com/wp-content/uploads/1192a1Sexual

Harassment.pdf; Barbara Frankel \& Stephanie Francis Ward, Little Agreement Between the Sexes on Tackling Harassment, Working Mother/ABA Journal Survey Finds, A.B.A. J. (July 24, 2018), http://www.abajournal.com/news/article/tackling_harassment_ survey_women_men; Stop Street Harassment, The Facts Behind the \#MeToo Movement: A National Study on Sexual Harassment and Assault 7-8 (2018), http://www.stop streetharassment.org/wp-content/uploads/2018/01/Full-Report-2018-NationalStudy-on-Sexual-Harassment-and-Assault.pdf (online survey found that 81 percent of women experience some form of sexual harassment during their lifetime; 38 percent in the workplace). Survey results differ depending on the operative definitions used. Smaller percentages of women report being victims of "sexual harassment," narrowly defined. U.S. Equal Emp't OPPORTUNity COMm'N, SELECT TASK ForCE ON THE STUdy of HARASSMENT in the WorkPlaCe: Report OF Co-Chairs Chai R. FEldBlum \& ViCTORIA A. LipNiC at 8-9 (2016), https://www.eeoc.gov/sites/default/files/migrated_files/eeoc/task force/harassment/report.pdf [hereinafter "EEOC TASK FORCE REPORT"]. But close to 60 percent of women report having experienced harassment when the term is used more broadly, to include not only sexual attention and coercion but also gender-based abuse such as the use of sexually crude epithets and posting of pornography. Id. at 9-10. Gender-based harassment is the most common form of harassment reported to researchers, and a clear gender differential exists in these cases: women are disproportionately the victims of sexual harassment, and men are disproportionately the perpetrators. Id. at 10; Rhitu Chatterjee, A New Survey Finds 81 Percent of Women Have Experienced Sexual Harassment, NAT'L Pub. RAdio (Feb. 21, 2018, 7:43 PM), https://www.npr.org/sections/thetwo-way/2018/02/21/587671849/a-new-surveyfinds-eighty-percent-of-women-have-experienced-sexual-harassment. 
comments or jokes, gender-based disparagement, displays or discussions of pornography, pressure for dates or sex, "accidental" or unwelcome touching, indecent exposure, or sexual assault.4 Such findings are consistent with the kinds of behavior men categorize as acceptable on the job. For example, a recent Harris Poll survey shows that close to 25 percent of men in eight countries, including the United States, believe it is acceptable for an employer to expect an employee to have "intimate interactions such as sex with them, a family member or a friend." 5 In a 2017 New York Times survey of male workers of varied age, job type, political affiliation, and marital status, close to 25 percent reported that they had told crude jokes or shared inappropriate videos at work; and 10 percent reported having imposed unwanted sexual attention on female colleagues, such as touching, commenting on a woman's body, or persisting in requesting dates after being turned down. ${ }^{6}$ Two percent admitted having coerced others into sex by threatening retaliation or offering an employment-related benefit. ${ }^{7}$

Why have we been so slow to impose meaningful change in response to this serious and deeply gendered harm? In March 2015, the Equal Employment Opportunity Commission (EEOC) sought to address this question head-on, creating a Task Force on the Study of Harassment in the Workplace. 8 The Task Force Co-Chairs defined their goals as follows:

With legal liability long ago established, with reputational harm from harassment well known, with an entire cottage

4 Feminist Majority Foundation, Sexual Harassment Fact Sheet, http://www.feminist.org/911/harasswhatdo.html [https://web.archive.org/web/201 91231153231/http://www.feminist.org/911/harasswhatdo.html].

5 New Global Poll: Significant Share of Men Believe Expecting Intimate Interactions, Sex from Employees Is Ok, CARE (Mar. 8, 2018), https://care.org/news-andstories/press-releases/new-global-poll-significant-share-of-men-believe-expectingintimate-interactions-sex-from-employees-is-ok/.

6 Jugal K. Patel, Troy Griggs \& Claire Cain Miller, We Asked 615 Men About How They Conduct Themselves at Work, N.Y. TImEs (Dec. 28, 2017), https://www.nytimes.com/ interactive/2017/12/28/upshot/sexual-harassment-survey-600-men.html.

7 See Patel et al., supra note 6. These results are particularly disturbing in light of the fact that this survey was based on self-reports-a type of research notorious for artificially deflated results, due to the human tendency to minimize one's own negative behavior. See, e.g., Robert Rosenman, Vidhura Tennekoon \& Laura G. Hill, Measuring Bias in Self-Reported Data, 2(4) Int. J. Behav. HealthCARE Res. 320, 330 (Oct. 2011), https://www.ncbi.nlm.nih.gov/pmc/articles/PMC4224297/ ("There are many reasons individuals might offer biased estimates of self-assessed behavior, ranging from a misunderstanding of what a proper measurement is to social-desirability bias, where the respondent wants to 'look good' in the survey, even if the survey is anonymous.").

8 Press Release, U.S. Equal Employment Opportunity Commission, EEOC to Study Workplace Harassment (Mar. 30, 2015) https://www.eeoc.gov/newsroom/eeoc-studyworkplace-harassment. 
industry of workplace compliance and training adopted and encouraged for 30 years, why does so much harassment persist and take place in so many of our workplaces? And, most important of all, what can be done to prevent it? After 30 years-is there something we've been missing? ${ }^{9}$

The Task Force report identifies several necessary structural changes in our systemic response to sexual harassment, each of which requires serious focus and reform. But it devotes only limited attention to a factor that goes straight to the heart of the problem: our reflexive inclination to discount the credibility of women, especially when those women are recounting experiences of abuse perpetrated by more powerful men. ${ }^{10}$ We will not succeed in ending gender-based workplace discrimination until we can understand and resist this tendency, and begin to appropriately credit survivors' stories.

The systematic undermining of women's reports of mistreatment flows directly from the instinctive, even unconscious methods we use to assess both the plausibility of the stories we hear and the trustworthiness of the people who tell them. ${ }^{11}$ When women share stories of abuse, they encounter a pervasive societal tendency to discount their credibility concerning both factors-story plausibility and individual trustworthiness. Credibility discounting silences many survivors, who accurately predict the limited likelihood that they will be believed upon coming forward. This, in turn, diminishes the accountability of those who harass, creating a vicious, permission-giving cycle of abuse of women in the workplace. ${ }^{12}$

9 EEOC TASK FORCE REPORT, supra note 3, at ii.

10 In fact, during the height of the \#MeToo movement, from 2017-18: The share of American adults responding that men who sexually harassed women at work 20 years ago should keep their jobs has risen from $28 \%$ to $36 \%$.... And $18 \%$ of Americans now think that false accusations of sexual assault are a bigger problem than attacks that go unreported or unpunished, compared with [a previous] 13\% .....

After a Year of \#MeToo, American Opinion has Shifted Against Victims, Economist (Oct. 15, 2018), https://www.economist.com/graphic-detail/2018/10/15/after-a-year-of-me too-american-opinion-has-shifted-against-victims.

11 See Deborah Epstein \& Lisa Goodman, Discounting Women: Doubting Domestic Violence Survivors' Credibility and Dismissing Their Experiences, 167 U. PENN. L. REv. 399 (2019). As Lauren Rikleen, an expert in the anti-discrimination field, puts it: "[W]omen do not tell their stories because they can't. Silence has long been the fuel that perpetuates bad conduct, but reporting that conduct has been weaponized against the victim in the form of character assassination, shaming, and disbelief." LAUREN RIKLEEN, The Shield of Silence: How Power Perpetuates a Culture of Harassment and Bullying in THE WORKPLACE 9 (2019).

12 See, e.g., RIKLEEN, supra note 11 , at 9. 
Credibility discounting ${ }^{13}$ similarly undermines women in the related contexts of domestic violence ${ }^{14}$ and sexual assault. ${ }^{15}$ In other words, credibility discounting occurs in every major context where (primarily) men are victimizing (primarily) women. This begs the question: Why do we routinely discount women's credibility, rather than according women the same level of trust and belief that we instinctively give to men? ${ }^{16}$

Part II of this Article analyzes how those charged with responding to workplace harassment-managers, supervisors, union representatives, human resource officers, and judges-improperly discount as implausible women's stories of harassment due to a failure to understand either the psychological trauma caused by abusive treatment or the practical realities that constrain women's options in its aftermath. Part III explores how we unjustly discount women's personal trustworthiness, based on their demeanor (as affected by the trauma they often have suffered); negative cultural stereotypes about women's motives for seeking redress for harms; and our deep-rooted cultural belief that women as a group are inherently less than fully trustworthy. Part IV explains the way gender-based credibility discounting fits into a larger "credibility economy" - the credibility discounts imposed on many women-victims must be understood in the context of the credibility inflations afforded to many male harassers. Part V examines the particular harms inflicted by discounting women's credibility. These harms can be measured as both an additional psychic injury to survivors, and as an institutional betrayal that echoes the harm initially inflicted by harassers themselves. Finally, Part VI offers suggestions for initial efforts to combat these unjust, gender-based credibility discounts. Adopting these reforms would set us on a path toward allowing women who are subjected to male abuses of workplace

13 The term "credibility discount" was originally coined by Deborah Tuerkheimer, in a thoughtful analysis of women's experiences of sexual assault. Deborah Tuerkheimer, Incredible Women: Sexual Violence and the Credibility Discount, 166 U. PENN. L. Rev. 1, 3 (2017). I used the same term in an article co-authored by Dr. Lisa Goodman, with a focus on how credibility discounts affect women survivors of domestic violence. I use the same term here in part to advance a dialogue about the universality of credibility discounting across contexts where women attempt to resist male abuses of power. Epstein \& Goodman, supra note 11, at 402.

14 For an extensive discussion of credibility discounting in the domestic violence context, see Epstein \& Goodman, supra note 11.

15 See Tuerkheimer, supra note 13.

16 This Article examines credibility discounting in the context of sexual harassment, drawing on the analysis presented in a previous piece, co-authored with Dr. Lisa Goodman, focused on domestic violence. Epstein \& Goodman, supra note 11, at 399. 
power to trust the responsiveness of their employers, judges, and our larger society.

\section{CREDibility Discounts Based on Story Plausibility}

\section{A. The Plausibility of Women's Stories of Workplace Harassment ${ }^{17}$}

Research tells us that the human brain is wired for stories. ${ }^{18}$ As we learn facts, we instinctively organize them into stories, in part to understand and test their plausibility. ${ }^{19}$ We "are, as a species, addicted to story. Even when the body goes to sleep, the mind stays up all night, telling itself stories."20

But when women survivors of workplace harassment tell their stories to employers, seeking protection, or to the justice system, seeking legal relief, their narratives often sound implausible, triggering a response of skepticism and disbelief. What are the reasons for this disconnect?

One factor contributing to story plausibility is internal consistency-we expect stories to ring true in terms of their linear development, as well as their logical and emotional nature. ${ }^{21}$ But many survivors are unable to articulate such stories about their experience. Their truthful recollections of workplace harassment are often imprecise and emotionally incongruous. And a major reason that survivor stories often fail to meet the test of internal consistency can be found in the psychological consequences of harassment itself.

Survivors of sexual harassment frequently experience psychological trauma, most often when the harassment is particularly degrading or frightening, or when it continues over an extended time. ${ }^{22}$

17 This introductory discussion of story plausibility is taken largely from Epstein \& Goodman, supra note 11, at 406.

18 Carolyn Grose \& Margaret E. Johnson, Lawyers, Clients \& Narrative: A Framework for LaW Students and Practitioners 15-16 (2017); see also Lisa Cron, Wired for Story: The Writer's Guide To Using Brain Science To Hook Readers from the Very First Sentence 185-99 (2012); David Chavkin, Clinical Legal Education: A TextBook For LaW School Clinical Programs 93-94 (2002); Kay Young \& Jeffrey L. Saver, The Neurology of Narrative, 30 SuBSTANCE 72, 74 (2001).

19 H. Porter Abbott, The Cambridge Introduction to Narrative 44 (2d ed. 2008). "For anyone who has read to a child or taken a child to the movies and watched her rapt attention, it is hard to believe that the appetite for narrative is something we learn rather than something that is built into us through our genes." Id. at 3.

20 Jonathan Gottschall, The Storytelling Animal: How Stories MaKe Us Human xiv (2012).

21 Epstein \& Goodman, supra note 11, at 407.

22 "The more degrading, frightening and sometimes physically violent, and the more frequently [sexual harassment] occurs over time' ... 'the greater chance of you having sustained mental health effects.'” Meera Jagannathan, These Are All the Ways Sexual 
Indeed, most survivors of workplace harassment meet the diagnostic criteria for Post-Traumatic Stress Disorder (PTSD). ${ }^{23}$

The symptoms associated with PTSD undermine survivors' ability to provide internally consistent accounts to co-workers, supervisors, human resource officers, and judges. Psychologically traumatic memories encode the physical and psychic harms that generate them in a way that often lacks verbal narrative detail and context, and that exist simply in the form of sensations, flashes, and images. ${ }^{24}$ Thus, PTSD inhibits a survivor's ability to link parts of a traumatizing story together; she may not be able to recall events in linear sequence or logically articulate her experience. ${ }^{25}$

In addition, an inability to recall key features of the traumatic event is common among those who develop PTSD. ${ }^{26}$ This undermines survivors' capacity to produce consistent and fully coherent narratives about their experiences in a way that can easily be improperly attributed to a lack of credibility. ${ }^{27}$

Thus, to a trauma expert, a woman's disconnected, inconsistent way of talking about her experience of harassment constitutes a strong indication that she was harassed and now suffers from PTSD. Indeed, this aspect of her story may well be evidence of the truth of her narrative

Harassment Can Make Your Life Miserable, MaRKetWAtch (Feb 15, 2018, 11:46 PM) https://www.marketwatch.com/story/these-are-all-the-ways-sexual-harassment-canmake-your-life-miserable-2018-02-15 (quoting clinical psychologist Joan Cook).

23 Bonnie S. Dansky \& Dean G. Kilpatrick, Effects of Sexual Harassment, in SEXUAL HARASSMENT: ThEoRY, RESEARCh, AND TREATMENT 152, 166 (W. O’Donohue ed., 1997); William Wan, Sexual Harassment Can Make Victims Physically Sick, Studies Reveal, ChiCAGo Tribune, (Feb. 8, 2018), https://www.chicagotribune.com/lifestyles/health/ctsex-harassment-victims-health-20180208-story.html. Sexual harassment also gives rise to other serious psychological symptoms, including reduced self-esteem, emotional exhaustion, lower life satisfaction, and substance abuse. Id.

24 Judith Lewis Herman, Trauma and Recovery: The Aftermath of Violence-From Domestic Abuse to Political Terror 38 (1997).

25 See, e.g., Jonathan E. Sherin \& Charles B. Nemeroff, Post-Traumatic Stress Disorder: The Neurobiological Impact of Psychological Trauma, 13 Dialogues CliniCAL NeuRosCienCE 263, 263 (2011) ("Several pathological features found in PTSD patients overlap with features found in patients with traumatic brain injury ...."); National Institute for the Clinical Application of Behavioral Medicine, How Trauma Impacts Four Different Types of Memory, https://www.nicabm.com/trauma-how-trauma-can-impact-4-types-ofmemory-infographic/ (explaining that trauma can significantly impair the formation and storage of memories, and can result in incapacitation of episodic memory and lead to memories that are fragmented in terms of event sequencing).

26 See Am. Psychiatric Ass'n, Diagnostic and Statistical Manual of Mental Disorders 271-72 (5th ed. 2013) [hereinafter DSMD].

27 Jim Hopper, Sexual Assault and Neuroscience: Alarmist Claims vs. Facts, PsYchoL. TodAY (Jan. 22, 2018), https://www.psychologytoday.com/blog/sexual-assault-andthe-brain/201801/sexual-assault-and-neuroscience-alarmist-claims-vs-facts [https://perma.cc/RG6P-EX38]. 
and make it all the more plausible. But the gatekeepers responsible for handling a woman's workplace harassment claim are likely to draw the opposite conclusion. To the untrained ear, these same features make her story sound suspect and implausible. Accordingly, those with the power to help her become safe or obtain justice are likely to impose a credibility discount: a manager, who is deciding whether to help her make a report; a human resource officer, who is deciding whether to take corrective or punitive action against her accused perpetrator; or a judge, who is deciding the outcome of her lawsuit. The more she tries to remain faithful to what she actually remembers, the more likely she is to be denied assistance, protection, and legal relief. ${ }^{28}$

Another major aspect of story plausibility is external consistencythe degree to which a story accords with how we expect the world to work. ${ }^{29}$ If a person, arriving late for a meeting in Washington, D.C., on a hot and humid summer day, explained that she was delayed because it took a long time to scrape the ice off her car, her story would not fit within a listener's sense of normalcy. To be externally consistent, she should be talking about how the weather created problems with her air conditioner, not the ice on her windshield. ${ }^{30}$

But our understandings of how the world works are deeply affected by a variety of unconscious processes and biases. Perhaps the greatest culprit here is "false consensus bias"-our unconscious propensity to wrongly see one's "own behavioral choices and judgments as relatively common and appropriate ... while viewing alternative responses as uncommon, deviant, or inappropriate." 31 False consensus bias tricks us into believing-mistakenly-that our personal experiences, attitudes, desires, and preferences are not individual, but

28 See Epstein \& Goodman, supra note 11, at 410.

29 GROSE \& JoHNSON, supra note 18, at 15-16; Epstein \& Goodman, supra note 11, at $412 \mathrm{n} .43$. As with internal consistency, the importance of external consistency in the related context of courtroom credibility determinations is reflected in treatises advising litigators about how to attack and undermine the credibility of a witness for the opposing side. See, e.g., Paul Bergman, Trial Advocacy In A Nutshell 62 (5th ed. 2013).

30 See Grose \& Johnson, supra note 18, at 16.

31 Lee Ross, David Greene \& Pamela House, The "False Consensus Effect": An Egocentric Bias in Social Perception and Attribution Processes, 13 J. Exp. Soc. Psychol. 279, 280 (1976); see also Leah Savion, Clinging to Discredited Beliefs: The Larger Cognitive Story, 9 J. ScholarShip TEACHING \& LEARNing 81, 87 (2009) ("People tend to over-rely on instances that confirm their beliefs, and accept with ease suspicious information."); Lawrence Solan, Terri Rosenblatt \& Daniel Osherson, False Consensus Bias in Contract Interpretation, 108 CoLUM. L. REv. 1268, 1268 (2008) ("Psychologists call the propensity to believe that one's views are the pre-dominant views, when in fact they are not, 'false consensus bias."'). 
are universal. ${ }^{32}$ We believe that our own thinking is just basic common sense and that, as a result, if we believe a certain thing or would behave in a certain way, other people will (or at least should) do the same. The pervasive and powerful nature of this bias is supported by extensive data across a wide variety of research studies. ${ }^{33}$

In truth, our experiences and the ways we understand the world are rarely as generalizable as we assume them to be. ${ }^{34}$ As noted by Epstein and Goodman, ${ }^{35}$ passengers who have experienced a serious car crash tend to react quite differently when a driver suddenly slams on the brakes than do those who have experienced only routine car rides. ${ }^{36}$ Veterans who have experienced military conflict often react quite differently to loud, unexpected noises than do civilians who have lived peaceful lives. ${ }^{37}$ And such expectations tend, in turn, to provoke diverse responses.

In the sexual harassment context, a crucial experiential gap exacerbates the scope of false consensus bias. On the one hand, there are those who have suffered workplace harassment, particularly harassment inflicted by someone with the ability to influence a survivor's job or career; on the other hand, there are those fortunate enough to have worked only in environments free from abuse.

It can be a real stretch for those who have not survived workplace harassment to comprehend many aspects of that experience, especially when the perpetrator seems, from an outside perspective, to be a decent

32 Epstein \& Goodman, supra note 11, at 412 n.46; Gary Marks \& Norman Miller, Ten Years of Research on the False-Consensus Effect: An Empirical and Theoretical Review, 102 Psychol. Bull. 72, 72 (1987); Ross, Greene \& House, supra note 31, at 280; Solan, Rosenblatt \& Osherson, supra note 31, at 1280.

33 Marks \& Miller, supra note 32 (noting that over a 10-year period, "over 45 published papers have reported data on perceptions of false consensus and assumed similarity between self and others").

34 Epstein \& Goodman, supra note 11, at 412-13 n.47.

35 The examples below are drawn from Epstein and Goodman, supra note 11, at $412-13$.

36 See J. Gayle Beck and Scott F. Coffey, Assessment and Treatment of Posttraumatic Stress Disorder After a Motor Vehicle Collision: Empirical Findings and Clinical Observations, 38 PROF. PsYCHOL. REs. \& PRAC. 629, 629 (2007) (explaining that survivors of motor vehicle accidents are at heightened risk of PTSD and may experience intrusive symptoms or avoid driving altogether).

37 See, e.g., Cariñez Dela Cruz Fajarito \& Rosalito G. De Guzman, Understanding Combat-Related PTSD Symptom Expression Through Index Trauma and Military Culture: Case Studies of Filipino Soldiers, 182 Military MED. e1665 (2017), https://academic. oup.com/milmed/article-pdf/182/5-6/e1665/21833747/milmed-d-16-00216.pdf.

For a vivid visual/aural exposition of the triggers veterans face in daily life, see David Lynch Found., Sounds of Trauma, YouTube (Apr. 11, 2017), https://www.youtube.com/ watch?v=bgpRw92d1MA. 
guy. Because survivors' stories can seem to lack external consistency, they again appear less plausible.

\section{Women Who Don't Report, or Don't Report Immediately}

To see the real-world impact of this interpretive gap, consider common expectations about whether and when a victim of sexual harassment will report the abuse. Recent \#MeToo stories of past harassment triggered a flurry of questions, presumably primarily from non-survivors, about why the victims did not report. ${ }^{38}$ Research demonstrates that non-survivors tend to assume that, if they were to find themselves in an abusive workplace environment, they would report the experience, and would do so immediately. ${ }^{39}$ This view does not appear to have changed significantly since now-Justice Clarence Thomas' confirmation hearings, when Senator Dennis DeConcini exclaimed, "If you've been sexually harassed, you ought to complain! ... . I mean, where's the gumption?" 40

And this non-survivor assumption holds for women as well as men. In a study where researchers conducted realistic job interviews with women, they asked members of one group how they thought they would react if a male interviewer asked them questions such as "Do you think it is important for women to wear bras to work?" 41 The women predicted that they would feel angry and would report the interviewer for sexual harassment. ${ }^{42}$ But when these inappropriate interview questions were actually posed to the other research group, the women reacted quite differently. 43 They reported feeling predominantly fear, rather than anger, and they made no effort to report.44 As the

38 E.g., Beverly Engel, Why Don't Victims of Sexual Harassment Come Forward Sooner?, Psychol. Today (Nov. 16, 2017), https://www.psychologytoday.com/us/blog/ the-compassion-chronicles/201711/why-dont-victims-sexual-harassment-comeforward-sooner.

39 See, e.g., Douglas D. Baker, David E. Terpstra and Kinley Larntz, The Influence of Individual Characteristics and Severity of Harassing Behavior on Reactions to Sexual Harassment, 22 Sex Roles 305, 315 (1990); James E. Gruber \& Michael D. Smith, Women's Responses to Sexual Harassment: A Multivariate Analysis, 17 BASIC \& APPLIED Soc. PsYCHOL. 543, 544 (1995); David E. Terpstra and Douglas D. Baker, The Identification and Classification of Reactions to Sexual Harassment, 10 J. ORG. BEH. 1 (1989).

40 Louise F. Fitzgerald, Suzanne Swan \& Karla Fischer, Why Didn't She Just Report

Him? The Psychological and Legal Implications of Women's Responses to Sexual Harassment, 51 J. Soc. IssuEs 117, 117 (1995) (quoting Senator Dennis DeConcini).

41 Julie A. Woodzicka \& Marianne LaFrance, Real Versus Imagined Harassment, 57 J.

Soc. Issues 15, 20-21 (2002).

42 Id. at 21.

43 Id. at 15

44 Id. 
researchers concluded, "anticipated behavior did not mesh with actual behavior." 45

Court decisions reflect this same false consensus bias. Judges routinely hold that it is inherently unreasonable for a victim to fail to file a formal report of sexual harassment with her employer. ${ }^{46}$ And all too frequently, these judges refuse to consider any aspect of the particular circumstances as relevant to a reasonableness determination, creating a de facto assumption that a failure to report is unreasonable per se. $4^{47}$ As Professor Joanna Grossman explains, courts take "a strict and entirely unrealistic view of how quickly and assertively employees must complain about harassment and how many obstacles they must overcome to do so." 48

Non-survivors also tend to assume that a victim will report immediately after the first episode of harassment. Courts reinforce this false assumption, holding that even brief delays between an incident of harassment and the victim's report are "unreasonable" under the law. ${ }^{49}$ In one case, for example, the plaintiff took seventeen days after the first incident of sexual harassment before filing a complaint. ${ }^{50}$ On September 28, her supervisor rubbed up against the side of her breasts; on October 11 or 12 , he put her head between his knees in a headlock. Three to four days after this last escalation, on October 15, she filed a formal complaint pursuant to the company's sexual harassment policy. ${ }^{51}$ The court held that the length of the period between the first incident and

45 Id.

46 See David Sherwyn, Michael Heise \& Zev J. Eigen, Don't Train Your Employees and Cancel Your "1-800" Harassment Hotline: An Empirical Examination and Correction of the Flaws in the Affirmative Defense to Sexual Harassment Charges, 69 FoRDHAm L. REv. 1265, 1286 (2001).

47 See Joanna L. Grossman, Moving Forward, Looking Back: A Retrospective on Sexual Harassment Law, 95 B.U. L. REv. 1029, 1045 (2015).

48 Id.; see also Kohler v. Inter-Tel Technologies, 244 F.3d 1167, 1181-82 (9th Cir. 2001); Hulsey v. Pride Restaurants, 367 F.3d 1238 (11th Cir. 2004) (court made no effort to investigate or explain why the plaintiff failed to report her supervisor's sexually harassing conduct under the particular circumstances that occurred).

49 See Shaba v. IntraAction Corp., No. 02 C 5173, 2004 WL 42350, at *1, *5 (N.D. Ill. Jan. 6, 2004) (finding unreasonable a two-month delay in reporting a supervisor's sexual harassment, during which the employee kept a log of incidents and discussed the issue with co-workers).

50 Conatzer v. Medical Professional Building Services, 255 F. Supp. 2d 1259, 1270 (N.D. Okla. 2003).

51 Id. at 1264. 
the formal complaint was unreasonable. ${ }^{52}$ Similar decisions have been handed down by judges in jurisdictions across the country. 53

As these examples demonstrate, for decades, most of us have assumed that the way the world works, and therefore what is externally consistent, is that a "real" victim would report and would do so quite quickly. But this is simply not the case. A meta-analysis of multiple studies found that only between a quarter and a third of those harassed ever report their experience to a supervisor or union representative, and only 2 to 13 percent file a formal complaint. 54 Multiple studies have found that approximately 70 percent of individuals who experienced harassment never even discussed it with a supervisor, manager, or union representative. 55 A recent survey of businesses and law firms found that although 68 percent of women respondents indicated that they had experienced workplace harassment, only 30 percent reported

52 Id. at 1270.

53 See, e.g., Pinkerton v. Colo. Dep't of Transp., 563 F.3d 1052, 1057, 1063 (10th Cir. 2009) (finding a reporting delay of approximately two months unreasonable when a supervisor asked the employee about her breast size, inquired if she masturbated, shared that he liked her skirt, and made comments about her ex-husband and children); Thornton v. Fed. Express Corp., 530 F.3d 451, 454, 458 (6th Cir. 2008) (finding a reporting delay of approximately two months unreasonable when a supervisor sexually harassed an employee for over two years, culminating in the employee having to take a leave of absence); Walton v. Johnson \& Johnson Servs., 347 F.3d 1272, 1292-93 (11th Cir. 2003) (concluding that a three-month delay was unreasonable as a matter of law where an employee was sexually harassed and raped by her supervisor on more than one occasion);Benson v. Solvay Specialty Polymers, No. 1:16-cv-04638, 2018 WL 5118615, at *18-19 (N.D. Ga. Jul. 3, 2018) (concluding that the employee's delay in reporting the harassment "equated to unreasonably failing to take advantage" of harassment policies where the employee was harassed by three colleagues on separate occasions and reported immediately the first time, within 15 days the second time, and within 2 months the third time); Mankowski v. Men's Warehouse, No. 04 C 6603, 2006 WL 208714, at*6 (N.D. Ill. Jan. 24, 2006) (concluding that a delay of approximately one month in reporting the harassment was unreasonable); Timothy M. Barber, Wisconsin Employment Law Letter: Sexual Harassment, When Can You Fire An Employee Who Fails to Timely Report Alleged Sexual Harassment, 26 No. 1 Wis. EMP. L. LeTTER 4 (Jan. 2017) (citing a case which concluded that an employee's reporting of an incident of butt slapping within one month was unreasonable because he was instructed to report immediately). Professor Grossman points out that the courts have placed survivors in a double bind: they must report harassment immediately to preserve their legal claims, but they will have no protection from retaliation if they report too early-at a point that the court subsequently determines is not yet legally actionable. Grossman, supra note 47 , at $1045-46$.

54 Lilia M. Cortina \& Jennifer L. Berdahl, Sexual Harassment in Organizations: A Decade of Research in Review, 25 Sage Handbook of Organizational Behav. 469, 485 (2008),

https://pdfs.semanticscholar.org/a41c/9c91cc084fede9faca785bf099ec7adb8264.pdf

?_ga=2.174325154.1215970955.1601413114-1520509921.1601413114.

55 Id. 
the incidents. ${ }^{56}$ And a similar picture emerged from a 2016 study in the United Kingdom, which found that four in five women do not report sexual harassment. 57

Why do women choose not to report? One of the (many) frequently-cited reasons is trepidation that their claims will not be believed. ${ }^{58}$ And this concern is realistic; an ABA survey showed that of those women who did report sexual harassment on the job, only 27 percent found that their complaints were taken seriously. ${ }^{59}$ As Professors Johanna Grossman and Deborah Rhode explain:

[Women] wait to see whether the behavior will stop on its own, or they keep silent because they fear that reporting will be futile.... Rather than filing internal or external complaints, harassment targets tend to resort to informal and nonconfrontational remedies. They vent, cope, laugh it off, treat it as some kind of less threatening misunderstanding, or simply try to get on with their jobs (and lives). They may blame themselves, pretend it is not happening, or fall into selfdestructive behaviors like eating disorders or drinking problems. ${ }^{60}$

Whatever the reason, the reality is clear: women rarely report even serious incidents of sexual harassment in the workplace.

Thus, a profound gap in understanding arises from the difference between non-survivor expectations and actual survivor behavior with respect to reporting. And this gap in comprehension creates real obstacles for survivors, who are likely to be met with skepticism when they do not conform to the expectations of others. Extensive and often high-profile media coverage, as well as a massive proliferation of laws, regulations, training programs, and anti-harassment policies, have not yet realigned the way many managers, union representatives, human

56 Frankel \& Ward, supra note 3.

57 Trades Union Congress, Still Just a Bit of Banter? Sexual Harassment in the WORKPLACE IN 2016 (2016), https://www.tuc.org.uk/research-analysis/reports/stilljust-bit-banter.

58 See, e.g., Workplace Harassment: Examining the Scope of the Problem and Potential Solutions: Meeting of the E.E.O.C. Select Task Force on the Study of Harassment in the Workplace (June 15, 2015), https://www.eeoc.gov/eeoc/task_force/harassment/ testimony_cortina.cfm (written testimony of Lilia M. Cortina).

59 Frankel \& Ward, supra note 3.

60 Joanna L. Grossman \& Deborah L. Rhode, Understanding Your Legal Options If You've Been Sexually Harassed, HARv. Bus. R. (June 22, 2017), https://hbr.org/2017/06/understanding-your-legal-options-if-youve-been-sexuallyharassed. The EEOC Report reached similar conclusions, finding that women are far more likely to pursue alternative strategies, such as avoiding the abusive co-worker, minimizing or denying their experience, or continuing to tolerate the harassment. EEOC TASK FORCE REPORT, supra note 3. 
resource offices, and judges go about making sense of what is, in fact, plausible survivor behavior. ${ }^{61}$

\section{Women Who Remain on the Job}

The pronounced disconnect between survivor and non-survivor perspectives on the world also strongly shapes common expectations about women's decisions to stay in their jobs and tolerate even terribly abusive treatment. Their reasons for staying vary. Some may remain on the job out of a realistic fear that their harasser will retaliate or blacklist them with other potential employers, causing real harm to their job prospects or careers. ${ }^{62}$ Others stay due to economic dependence; they have no other options that will allow them to pay the bills or support their children.63 Others remain to preserve their professional ambition, understanding that they are dependent on their harasser for mentorship and professional advancement.64 For all of

61 Seventy percent of employers provide sexual harassment training; 98 percent of companies have sexual harassment policies. Simplify Complance Training, Federal Training Requirements (citing a Bureau of Labor and Statistics (BLS) survey), https://simplifytraining.com/article/federal-training-requirements/ (last visited Sept. 29,2020 ). Nonetheless, more than 12,000 sexual harassment claims were filed with the EEOC in 2015. U.S. EQUal EmP. OPPORTUnity Comm'n, Charges Alleging SEX-BASEd HARASSMENT (CHARGES FILED WITH EEOC) FY2010-FY2019, https://www.eeoc.gov/ statistics/charges-alleging-sex-based-harassment-charges-filed-eeoc-fy-2010-fy-2019.

62 See, e.g., Joshua Barajas \& Elizabeth Flock, They Reported Sexual Harassment. Then the Retaliation Began, PBS News Hour (Mar. 1, 2018), https://www.pbs.org/newshour/ nation/they-reported-sexual-harassment-then-the-retaliation-began (women members of the California Forest Service face a choice of either reporting harassment and facing retaliation, or staying on the job); Jim Rutenberg, Emily Steel \& John Koblin, At Fox News, Kisses, Innuendo, Propositions and Fears of Reprisal, N.Y. Times (Jul. 23, 2016), https://www.nytimes.com/2016/07/24/business/at-fox-news-kisses-

innuendo-propositions-and-fears-of-reprisal.html?module=inline (when the New York Times spoke with women who experienced sexual harassment by supervisors at Fox News, the women requested to remain anonymous for "fear of retribution," getting fired, and/or "damage [to] their careers"); Bernice Yeung, Rape on the Night Shift, FronTLinE (Jun. 23, 2015), https://www.pbs.org/wgbh/frontline/article/rape-on-the-night-shift/ (women janitors are easy targets for sexual abuse on the job but are not likely to leave).

63 See, e.g., Danya Evans, Don't Leave Their Jobs After They've Been Sexually Harassed, Cut (Aug. 5, 2016), https://www.thecut.com/2016/08/why-women-stay-at-jobs-aftersexual-harassment.html (telling story of one woman who stayed in a job despite harassment because she needed the salary; she was a "single mom with two kids" and there was "no way [she] was going to quit;" and another who stayed at her job because she needed the health insurance to support her baby and did not have the time to do a job search); Alissa Quart, What's the Common Denominator Among Sexual Harassers? Too Often, it's Money, GUARDIAN (Nov. 9, 2017), https://www.theguardian.com/us-news/ $2017 /$ nov/09/sexual-harassment-economic-inequality-harvey-weinstein (a woman stayed at her job for a decade despite harassment because she needed to support her family).

64 For example, women who were harassed and assaulted when working for Charlie Rose explained that they stayed on the job for professional advancement reasons. Amy 
these reasons, those who have experienced workplace harassment understand that a decision to stay on the job and tolerate continued abuse is just how the world works for many women; it is a normal response to a difficult situation where, in reality, few options exist.

But many of those who are privileged enough to have not experienced workplace harassment, or who have numerous available job options, or who have a substantial financial cushion, find that they cannot understand the choice to stay. Donald Trump echoed this failure in comprehension when he was asked to imagine his daughter being subjected to workplace harassment. He said this would pose no problem; Ivanka would simply find another company to work for or would start another career.65 Eric Trump also echoed this gap in experiential understanding, saying that his sister would just never allow sexual harassment to happen to her.66

In other words, for many who are not survivors of sexual harassment, a woman's decision to tolerate harassment and stay in her job is deeply inconsistent with how they expect people to act in the world. It simply does not make sense; to them, it sounds as unlikely as ice on a car windshield during a D.C. summer. When these listeners hear stories of women who are behaving as a prototypical survivor would, they wrongly perceive these stories to be externally inconsistent and thus impose an unfair, discriminatory credibility discount.

Brittain \& Irin Carmon, Eight Women Say Charlie Rose Sexually Harassed Them-with Nudity, Groping, and Lewd Calls, WASH. PosT (Nov. 20, 2017), https://www.washington post.com/investigations/eight-women-say-charlie-rose-sexually-harassed-themwith-nudity-groping-and-lewd-calls/2017/11/20/9b168de8-caec-11e7-8321-

481fd63f174d_story.html. One woman stated that she stayed because "there are so few jobs" in the television industry and that if she didn't stay, someone else would get this scarce position. Id. Another said she stayed because she was told that "personal time with Rose was a key to becoming part of the team." Id. Similarly, many women stayed in their jobs at the Ford Union plant in Chicago, despite harassment, because a "job at Ford was considered a golden ticket." Susan Chiara \& Catrin Einhorn, How Tough Is It to Change a Culture of Harassment? Ask Women at Ford, N.Y. Times (Dec. 19, 2017), https://www.nytimes.com/interactive/2017/12/19/us/ford-chicago-sexualharassment.html.

65 Scott Bixby, Eric Trump: 'Strong, Powerful Women' Don't Allow Sexual Harassment to Occur, GuARDIAN (Aug. 2, 2016), https://www.theguardian.com/us-news/2016/aug/ 02/eric-trump-donald-ivanka-sexual-harassment. See also, e.g., Sexual Harassment in the Workplace, A CASE FOR WOMEN, https://www.acaseforwomen.com/sexual-

harassment/ ("[T]here is this completely maddening myth widely circulated in the media that goes something like: 'Strong women don't get sexually harassed at work; strong women stand up for themselves at work, and so they are protected.'”).

66 Bixby, supra note 65. 
This creates a problematic dichotomy. Both survivors and experts in the field are likely to recognize a woman's story about her response to harassment as realistic and fully plausible. 67 But that same woman is likely to find that her actions are perceived as implausible by many in her workplace and in the larger society who lack either experience or expertise, and who then discount her credibility. ${ }^{68}$

\section{CREDibility Discounts BASED ON STORYTELLER TRUSTWORThinesS}

In addition to discounting the plausibility of the stories told by women survivors, we also discount the individual trustworthiness of women as narrators of stories. ${ }^{69}$ In other words, regardless of the content of her story, a woman may be considered an unreliable reporter of her own experiences. Our assessment of women's personal trustworthiness suffers from skepticism rooted in (1) uneducated expectations regarding a survivor's "appropriate" demeanor; (2) prejudicial stereotypes regarding the false motives of women seeking material assistance; and (3) the long-standing cultural tendency to disbelieve women simply because they are women.

\section{A. Survivor Demeanor}

When a survivor tells the story of the harassment she has experienced, her demeanor may be symptomatic of psychological trauma induced by the abuse itself. Three core aspects of PTSDnumbing, hyperarousal, and intrusion-can influence demeanor in obvious ways. This, in turn, can cause system gatekeepers to misinterpret-and, as a result, discount-the credibility of women who display each set of symptoms when telling their stories of workplace harassment. 70

First, a survivor can respond to overwhelming trauma by becoming emotionally numb, a compensating psychic response that often manifests as a highly-constrained affect. ${ }^{71}$ This symptom can profoundly shape the way a woman appears when making a report and, in turn, how a manager, human resource officer, union representative, or judge perceives her. Numbing may cause many survivors to talk or

67 Epstein \& Goodman, supra note 11, at 419.

68 See, e.g., Rachel McKinnon, Allies Behaving Badly: Gaslighting as Epistemic Injustice, in Routledge HandBook of EPISTEMic InJustice 167, 170 (Ian James Kidd et al. eds., 2017) [hereinafter RouTLEDGE HANDBOOK].

69 Epstein \& Goodman, supra note 11, at 420.

70 DSMD, supra note 26, at 271-72. This discussion of the various aspects of PTSD borrow heavily from Epstein \& Goodman, supra note 11, at 421.

71 DSMD, supra note 26 , at 272. 
testify about emotionally charged incidents with an entirely flat affect.72 A woman may tell a story about how her supervisor sexually assaulted her in the same tone she would use to describe what she ate for dinner. This disconnect between affect and story can be jarring and can result in the imposition of a credibility discount.

PTSD also alters demeanor via hyperarousal: a state of feeling overly alert, keyed-up, paranoid about danger, easily agitated, overly aggressive, or threatened even when not really in danger. ${ }^{73}$ Symptoms of hyperarousal can result in a victim appearing "highly paranoid or subject to unexpected outbursts of rage in response to relatively minor incidents."74 In the office, for example, a harassing supervisor may make a particular comment or adopt a particular tone of voice when speaking to a victim. Others may not notice anything out of the ordinary, but the target-victim does: she knows that he is communicating a message of intimidation or threat. This may cause her to react in ways that appear, on the surface, out of control-perhaps even crazy. ${ }^{75}$ She now fits the stereotype of a hysterical female-an image commonly associated with exaggeration and unreliability. ${ }^{76}$ Those around her are therefore more likely to apply a credibility discount and assume that, regardless of the content of her story, the survivor is not a fully trustworthy person.

Finally, PTSD symptoms affect demeanor through intrusion: experiencing vivid memories or flashbacks that make the survivor feel as though the trauma is recurring. ${ }^{77}$ These symptoms can be so overwhelming that a survivor cannot coherently tell her story. ${ }^{78}$

All of this places sexual harassment victims in a double bind. The very symptoms of their trauma-the reliable indicators that abuse has occurred-are wielded against them to damage their credibility. Because PTSD symptoms can make women appear unusually hysterical,

72 Deborah Epstein, Effective Intervention in Domestic Violence Cases: Rethinking the Roles of Prosecutors, Judges, and the Court System, 11 YALE J.L. \& FEMINISM 3, 41 (1999); see also Mary Ann Dutton, Understanding Women's Responses to Domestic Violence: A Redefinition of Battered Woman Syndrome, 21 Hofstra L. REv. 1191, 1198 n.36 (1993); HERMAN, supra note 24, at 45.

73 Epstein, supra note 72, at 41.

74 Id.

75 See Mary Przekop, One More Battleground: Domestic Violence, Child Custody, and the Batterers' Relentless Pursuit of their Victims Through the Courts, 9 SEATTLE J. Soc. Just. 1053, 1078-79 (2011).

76 See id. at 1079 ("Female jurors, according to one study, already believe that women are generally 'less rational, less trustworthy, and more likely to exaggerate than men."').

77 DSMD, supra note 26 , at 275.

78 Epstein, supra note 72, at 41. 
angry, paranoid, flat, or numb, they contribute to credibility discounts that may be imposed by system gatekeepers at all levels. ${ }^{79}$

And the skeptical reactions of system gatekeepers to survivor demeanor can trigger a vicious cycle of credibility discounts. The more a human resource officer, manager, or judge appears to doubt a survivor's credibility, the more likely she is to feel upset, destabilized, or even (re)traumatized. ${ }^{80}$ This reaction may trigger an increase in the intensity of her emotionally "inappropriate" demeanor, making her appear even less credible. ${ }^{81}$

\section{B. Survivor Motive}

To assess the trustworthiness of a woman's account of genderbased harassment, employers and others are inevitably (though perhaps unconsciously) influenced by stereotypical beliefs about women, particularly in the context of workplace relationships. ${ }^{82}$ Although individuals vary in the stereotypes they hold, certain fundamental cultural tropes about women's motives to lie and manipulate tend to resonate in situations where women assert that they have been harmed by the men in their lives. ${ }^{83}$

One of the most persistent and virulent stereotypes about women's false allegations about male behavior is the "grasping, system-gaming woman on the make." 84 We tend to discount the trustworthiness of

79 See, e.g., Epstein, supra note 72, at 41-42.; Cheryl Hanna, No Right To Choose: Mandated Victim Participation in Domestic Violence Prosecutions, 109 HaRv. L. Rev. 1849, 1878 (1996); Laurie S. Kohn, Barriers to Reliable Credibility Assessments: Domestic Violence Victim-Witnesses, 11 AM. U. J. GENDER Soc. PoL'Y \& L. 733, 742 (2003).

80 See Jennifer Saul, Implicit Bias, Stereotype Threat, and Epistemic Injustice, in ROUTLEDGE HANDBOOK, supra note 68, at 238.

81 Id.

82 Philosopher Kristie Dotson calls this "testimonial quieting." Kristie Dotson, Tracking Epistemic Violence, Tracking Practices of Silencing, 26 HYPAтіA 236, 242-43 (2011). Sexual harassment is typically a manifestation of a broader pattern of inequality and discrimination in the workplace. See generally Vicki Schultz, Open Statement on Sexual Harassment from Employment Discrimination Law Scholars, 71 STAN. L. REv. ONLINE 17 (2018). "Without the power and safety that comes with equal representation and numbers, women cannot effectively counter stereotypes or[, in turn,] deter or resist harassment." Id. at 24.

83 Professor Amy Ronner identified five stereotypes about women as liars in the context of sexual harassment litigation: the woman who asked for it, the woman scorned, the woman who lusts after money, the woman of hyperbole, and the woman of delusions. Amy D. Ronner, The Cassandra Curse: The Stereotype of the Female Liar Resurfaces in Jones v. Clinton, 31 U.C. DAvIs L. REv. 123, 134-38 (1997). This article will explore one of these five in depth: the "gold digger."

84 Epstein \& Goodman, supra note 11, at 425. The "woman scorned" is another gender-based stereotype commonly applied to women claiming sexual harassment. The 
women who appear motivated by the desire to get something from the men in their lives.

The "grasping woman" stereotype was popularized in the film Gold Diggers of 1933, which portrayed a group of aspiring actresses seeking to marry millionaire bachelors during the Great Depression. ${ }^{85}$ Since then, the gender makeup of the American workplace has undergone a seismic change: 49 percent of employed women now report that they are the primary breadwinners in their households. ${ }^{86}$ Although this reality stands in sharp contrast to the gold digger myth, the stereotype

proverb, "hell hath no fury like a woman scorned," is adapted from a line in an eighteenth-century English drama:

Heav'n has no Rage, like Love to Hatred turn'd,

Nor Hell a Fury, like a Woman scorn'd.

William Congreve, The Mourning Bride (1697), reprinted in The Mourning BRIDE, Poems, \& Miscellanies By William Congreve 125 (Bonamy Dobree ed. 1928). During Anita Hill's congressional testimony about her experiences with Clarence Thomas when he supervised her, Senator Howell Heflin (an Alabama Democrat) asked her, "Are you a woman scorned?" Erin Blakemore, How Anita Hill's Confirmation Hearing Testimony Brought Workplace Sexual Harassment to Light, History (Apr. 23, 2018), https://www.history.com/news/anita-hill-clarence-thomas-sexual-harassment-

confirmation-hearings. Women branded with this stereotype are assumed to be motivated by a desire to punish a man for rejecting her. "Society depicts her as wielding the sexual harassment claim as a retributive workplace sword.... [T] he underlying assumption is that she is not the harmed but rather the harmer." Ronner, supra note 83, at 136. This stereotype that women lie out of a desire for revenge after being romantically or sexually rejected is alive and well today. See, e.g., Meghan Grant, Alexander Wagar Says Woman Accusing Him of Sexual Assault is Out for "Revenge," CBC News (Nov. 8, 2016), https://www.cbc.ca/news/canada/calgary/alexander-wagarsexual-assault-trial-cross-examination-1.3841965. And after Larry Nassar, a sports therapist at Michigan State University who sexually assaulted more than 150 female students over two decades, was convicted on multiple counts, he submitted a sentencing letter to the court using the phrase, "hell hath no fury like a woman scorned," to claim that-despite the jury verdict against him-his accusers were not credible. Des Bieler, Here are the Larry Nassar Comments that Drew Gasps in the Courtroom, WASH. Post (Jan. 24, 2018), https://www.washingtonpost.com/news/early-lead/wp/2018/01/24/here-are-the-larrrynassar-comments-that-drew-gasps-in-the-courtroom/?utm_term=.d624fa23a0b1. For more information about the Larry Nassar case, see Caroline Kitchener, Larry Nassar and the Impulse to Doubt Female Pain, ATLANTIC (Jan. 23, 2018, 10:23 PM), https://www.theatlantic.com/ health/archive/2018/01/larry-nassar-and-the-impulse-to-doubt-female-pain/551198/.

85 GOLD DigGERS OF 1933 (Warner Bros. 1933) (portraying aspiring actresses experiencing financial hardship who conspire to find wealthy husbands). "[I]t's a weird form of gaslighting to deny women the right to earn money, vote, or own property, education or anything else that would allow them to earn on par with men - and burden them with total responsibility for child rearing - but then accuse them of being ruthlessly shallow when they look for a guy with plenty of money to go around." Tracy Moore, What's Does [sic] 'Gold Digger' Mean These Days?, Mel Mag. (Apr. 6, 2018), https://melmagazine.com/en-us/story/whats-does-gold-digger-mean-these-days.

86 Shawn M. Carter, More Women are the Breadwinner at Home, But Most Still Say Men Treat Them Differently at Work, CNBC (Mar. 23, 2018, 12:44 PM), https://www.cnbc.com/2018/03/23/more-women-are-breadwinners-but-are-stilltreated-differently-at-work.html. 
persists. As one example, in Silicon Valley, tech magnates swap warnings about women they refer to as "founder hounders" who pursue relationships with wealthy men who head start-up companies.87 Although the idea that a significant number of such women exist is at best debatable, the stereotype is alive and well, at least among the wealthy men who fear they might fall victim. ${ }^{88}$

The social myth of the gold digger is particularly lethal for women seeking protection and redress for workplace harassment. This ugly term has been applied to many women who have come forward as part of \#MeToo, and it has served as a powerful tool to undermine their credibility. Here is how it typically plays out: Many women who report workplace harassment are subject to real retaliatory harms, many of which have attendant financial implications. ${ }^{89}$ Such retaliation may take a variety of forms such as depressed job evaluations, denials of raises and promotions, unwelcome transfers, or poor references to other employers. ${ }^{90}$ Moreover, evidence suggests that those who respond most

87 See Emily Chang, "Oh My God, This Is So F---ed Up": Inside Silicon Valley's Secretive, Orgiastic Dark Side, VANITY FAIR (Jan. 2, 2018), https://www.vanityfair.com/news/ 2018/01/brotopia-silicon-valley-secretive-orgiastic-inner-sanctum.

88 Id.

89 A 2016 Trades Union Congress study, conducted in the United Kingdom with the Everyday Sexism Project, found high rates of both management passive inaction and active retaliation against women who reported sexual harassment. See generally TraDES UNION CONGRESS, supra note 57, at 20. Among women who reported, 70 percent found that their situations remained unchanged; 16 percent said that their situations got worse. Id. at 19. Another study of public-sector employees found that two-thirds of workers who complain about mistreatment experience retaliation. Carly McCann, Donald Tomaskovic-Devey \& M.V. Lee Badgett, Employer's Responses to Sexual Harassment, U. MASS. AMHERST: CENT. FOR EMP. EQUITY, https://www.umass.edu/ employmentequity/employers-responses-sexual-harassment ("most employers react punitively to people who file sexual harassment charges" and 68\% of the harassment charges filed with the EEOC also allege retaliation); Janet Nguyen \& David Brancaccio, Survey Finds that in Tech, Retaliation for Speaking Up about Workplace Discrimination is Common, MARKETPLACE (Jul. 24, 2018) https://www.marketplace.org/2018/07/24/ business/retaliation-workplace (survey of over 4,000 tech company employees showed over $40 \%$ faced retaliation after reporting harassment).

90 See, e.g., Nicole Buonocore Porter, Ending Harassment by Starting with Retaliation, 71 Stan. L. Rev. Online 49, 50 (2018); Fitzgerald, Swan \& Fischer, supra note 40, at 122-23; Joshua Barajas \& Elizabeth Flock, They Reported Sexual Harassment. Then the Retaliation Began, PBS: NEws Hour (Mar. 1, 2018, 5:14 PM), https://www.pbs.org/ newshour/nation/they-reported-sexual-harassment-then-the-retaliation-began (retaliation through verbal threats, bullying, stripping of duties, negative performance review, and demotion); Yuki Noguchi, Advice for Dealing With Workplace Retaliation: Save Those Nasty Emails, NAT'L PuB. RAdio: Morning EdITION (Sept. 14, 2016, 4:51 AM), https://www.npr.org/2016/09/14/493788339/advice-for-dealing-with-workplaceretaliation-save-those-nasty-emails (retaliation may take the form of demotion, bad evaluation, or undesirable assignment); see also RIKLEEN, supra note 11, at 44; Anne Lawton, Between Scylla and Charybdis: The Perils of Reporting Sexual Harassment, 9 U. 
assertively to harassment-for example, by filing formal complaintsreceive the most negative retaliatory treatment. ${ }^{91}$ In recognition of this fact, the law entitles victims to various forms of financial compensation.

But many women who pursue such compensation through the courts end up being perceived as "gold diggers" who are exaggerating or fabricating their story of harassment for money. ${ }^{92}$ The gold digger stereotype, in turn, results in women being treated with skepticism about their credibility. In fact, all these women are actually doing is seeking the full scope of remedies that the law provides and trying to regain the position they would have been in but for the discriminatory harassment to which they were subjected.

[Only a] tiny fraction of the workforce files a discrimination suit in any given year.... Available social science evidence does not support any significant faker problem. Instead, it actually shows that employees are reluctant to believe that their employers discriminated against them. ${ }^{93}$

Despite this fact, the idea that women survivors of workplace harassment are "gold diggers" motivated by something other than safety and fairness tends to fall on receptive ears in our society in general, and in our justice system in particular, because of this virulent, derogatory stereotype. An important lesson from Taylor Swift's successful sexual harassment suit against a disk jockey is that by filing the suit for the

PA. J. LAB. \& EMP. L 603, 611-12 (2007) (retaliation took the form of reputation-damaging misrepresentations and more stringent tenure requirements).

91 TRADES UNION CONGRESS, supra note 57, at 18-24.

92 This stereotype is often paired with the misogynist assumption that only young, attractive women could be sexually harassed. There are websites abounding with vicious comments about plaintiffs in workplace discrimination suits being too old or too ugly ("hardly a virgin or a hottie") to be credible as victims. Why Are Women Filing So Many Frivolous Sexual Harassment Lawsuits?, BLot MAG. (Aug. 4, 2014), https://www.the blot.com/women-filing-many-sexual-harassment-lawsuits-greedy-just-7755878 (stating that a forty-year-old professor at Columbia Business School who filed a sex discrimination suit was "hardly a hottie or a virgin"). In Italy, a fifty-year-old woman president of a female soccer club sued Carlo Tavecchio, head of Italy's national soccer federation, for twice groping her breasts, once while he was being videotaped by a hidden camera police had suggested that she wear. Subsequently, however, prosecutors dropped the case, in part based on their conclusion that she was "too old to be distressed by his advances." Lorenzo Tondo \& Stephanie Kirchgaessner, Italian Groping Case Dropped Because Alleged Victim was "Too Old to be Scared," GuARdian (June 14, 2018), https://www.theguardian.com/world/2018/jun/14/italy-groping-case-carlo-

tavecchio-prosecutors-report; see also Lux Alptraum, Sexual Assault Isn't a "Pretty Girl Problem," SPLINTER (Oct. 14, 2016, 9:04 AM), https://splinternews.com/sexual-assaultisn-t-a-pretty-girl-problem-1793862809 (describing the discriminatory harm arising from understanding sexual harassment as a "pretty girl problem").

93 Sandra F. Sperino \& Suja A. Thomas, Unequal: How America's Courts Undermine Discrimination Law 143, 145 (New York: Oxford University Press, 2017). 
symbolic amount of one dollar she substantially bolstered her credibility in ways that most women cannot afford to do. ${ }^{94}$

What is the practical result for a woman who experiences workplace harassment? She often faces an untenable and unfair choice. On the one hand, she could go to trial and seek the full panoply of relief she needs to obtain justice and hold her harasser accountable, but in doing so risk being found incredible and losing her entire case. On the other hand, she could severely limit the financial relief she seeks simply to be found credible. Finally, she could sign a legal nondisclosure agreement to obtain the financial relief she needs but give up on telling her story publicly and protecting other women from future harassment. No one should have to face such an untenable set of choices.

Gender stereotypes are, of course, also shaped by stereotypes about race, class, and other identities. ${ }^{95}$ As with all stereotypes, those that affect women as women are not monolithic in their impact: gender discounts are racialized (for example, the unrapeable black woman) and racial discounts are gendered. Despite this diversity of impact and complexity of harm, the bottom line remains the same: we tend to discount the trustworthiness of all women who appear to be motivated by a desire to get something.

\section{Survivors as Women}

Cognitive psychologists know that our culture-as translated by the media, authority figures, family members, etc.-teaches us stereotypes that we then adopt on a deep, unconscious level. ${ }^{96}$ The most ubiquitous derogatory stereotypes include many that devalue the credibility of women, people of color, those living in poverty, and other marginalized groups. Once formed, these stereotypes tend to be highly resistant to counter-evidence. ${ }^{97}$

94 See, e.g., Hilary Weaver, Taylor Swift Has Finally Been Sent the Symbolic Dollar She Won in Court, VANITY FAIR (Dec. 7, 2017), https://www.vanityfair.com/style/2017/12/ former-dj-david-mueller-says-he-sent-taylor-swift-dollar-payment.

95 Epstein \& Goodman, supra note 11, at 427.

96 See, e.g., Rachel D. Godsil et al., 2 The Science of Equality: The Effects of Gender Roles, Implicit Bias, and Stereotype Threat on the Lives OF WOMEN ANd GiRls 12 (2016), https://equity.ucla.edu/wp-content/uploads/2016/11/Science-of-Equality-Volume2.pdf ("Popular culture plays an important part in reinforcing these gendered associations. Implicit biases are not the result of individual psychology-they are a social phenomenon that affects us all.").

97 Jeremy Wanderer, Varieties of Testimonial Injustice, in RouTLEDGE HANDBOoK, supra note 68 , at 28 . 
The stereotype most directly relevant here relates to the persistent practice of discounting women's credibility as women. The idea that women are more likely than men to dissemble, manipulate, and misinform goes back as far as Aristotle, who attributed what he saw as the female tendency to lie to the "fact" that women were created as inferior versions of men. ${ }^{98}$ He claimed that women were less logical and more emotionally dysregulated than their male counterparts. ${ }^{99}$

Today, strong messages about women's lack of trustworthiness still abound. A stark example of this gender-based difference can be seen through the work of women organizers who have created a catharsis-focused online project called That's What She Said.100 Through this project, women submit first-person narratives of experiences that revolve around their gender.101 Then, at campus events, men take the stage one at a time and are handed an envelope containing one of the stories. ${ }^{102}$ They read the women's stories in their male voices, creating a sense of cognitive dissonance that highlights the absurdity of this gendered credibility discounting. ${ }^{103}$ One example:

I was waiting in line with friends at a club in Boston. When it came time for us to enter, the bouncer ranked us by our "hotness," letting the "hot" ones in first.

When it was finally my turn, he wouldn't let me enter until I "smiled." I asked why, and he said that I was only pretty when I smiled. I told him I didn't feel like smiling, told him that he shouldn't tell women to smile.

98 Aristotle claimed that women are "more mischievous, less simple, more impulsive ... more compassionate... more easily moved to tears ... more jealous, more querulous, more apt to scold and to strike ... more prone to despondency and less hopeful ... more void of shame or self-respect, more false of speech, more deceptive, of more retentive memory [and] ... also more wakeful; more shrinking [and] more difficult to rouse to action" than men. ARISTOTLE, History of Animals (D'Arcy Wentworth Thompson trans.) https://penelope.uchicago.edu/aristotle/histanimals9.html.

99 Id.; see also Elise Hu, Why Some Survivors of Sexual Harassment and Assault Wait to Tell Their Stories, NaT'L Pub. Radio: All Things Considered (Nov. 15, 2017, 4:42 PM), https://www.npr.org/2017/11/15/564443807/why-some-survivors-of-sexual-

harassment-and-assault-wait-to-tell-their-stories.

100 THAT's WHAT SHE SAID, https://www.thatswhatshesaidco.org/ (last visited Sept. $13,2020)$.

101 About, That's What She SAID, https://www.thatswhatshesaidco.org/about (last visited Sept. 13, 2020).

102 Id.

103 Id. 
He didn't let me in the club. ${ }^{104}$

This tendency to discount women's credibility is particularly strong for women who are seen as physically attractive. A University of Colorado study found that study participants consistently viewed attractive women as less truthful than either those men or women whom crowdsourcing research rated as less attractive. ${ }^{105}$

In addition, there is a tendency to discount a woman's credibility when her views are accompanied by emotional expression. As the new discipline of psychology developed in the nineteenth century, experts agreed that emotion in women (but not in men) was "the enemy of true rationality." 106 This idea persists today. A 2016 study found that both men and women implicitly associate "male" with rationality and thinking and "female" with emotionality and feeling.107 Similarly, Professor Joan Williams of the Center for WorkLife Law surveyed close to 3,000 lawyers about their experiences with emotional expression in the workplace. The white men in her sample reported feeling free to express anger at the office, in contrast to only 44 percent of white women and only 40 percent of women of color. ${ }^{108}$ Indeed, most women reported being penalized for displaying anger at the office. ${ }^{109}$

The societal tendency to discount women as inherently overemotional, illogical, and even crazy, can also be seen in the etymology of our language. The word "hysterical" derives from the Latin hystericus, or "of the womb."110 It was long believed that a dysfunction of the uterus could trigger insanity in women.111 The word "lunacy" derives from a belief that women suffered from monthly insanity triggered by the cycles of the moon-which were viewed as

104 Read What She Said, ThAт's WhAт SHE SAID, https://www.thatswhatshesaidco.org/ read-what-she-said (last visited Sept. 13, 2020).

105 See Leah D. Sheppard \& Stefanie K. Johnson, The Femme Fatale Effect: Attractiveness is a Liability for Businesswomen's Perceived Truthfulness, Trust, and Deservingness of Termination, 81 SEX RolEs 779 (2019).

106 Stephanie A. Shields, Passionate Men, Emotional Women: Psychology Constructs Gender Difference in the Late 19th Century, 10 Hist. of Psych. 92, 98, 102 (2007).

107 See Olivia Pavco-Giaccia, Rationality is Gendered: Using Social Cognition to Explore the Thinking/Feeling Bias (Apr. 22, 2016) (unpublished B.A. thesis, Yale University), https://cogsci.yale.edu/sites/default/files/files/Thesis2016Pavco Giaccia.pdf.

108 Joan C. Williams et al., You Can't Change What You Can't SeE: Interrupting Racial \& Gender Bias in the Legal Profession 25 (2018).

109 Id. at 6; Victoria Brescoli \& Eric Uhlmann, Can an Angry Woman Get Ahead? Status Conferral, Gender, and Expression of Emotion in the Workplace, 19(3) PsYcHOL. SCI. 265 (2008).

110 See, e.g., Hysteria, MERRIAm-WEBSTER DictionARY, https://www.merriamwebster.com/dictionary/hysteria (last visited Aug. 17, 2020).

111 See id. 
connected to women's menstrual cycles. ${ }^{112}$ These terms underscore our fundamentally different understandings of "female and male mental states: men being historically associated with rationality, straightforwardness and logic; women with unpredictable emotions, outbursts and madness." 113

Similarly, the Urban Dictionary defines "female logic" as:

An oxymoron of the greatest magnitude. Male logic (or just plain logic) follows a direct path, clearly tying the consequences of action to the actor. Female logic doesn't follow a direct path. Female logic always contains ... something to blame her actions on just in case something goes wrong .... Essentially, female logic is to do whatever you want and then justify it with unrelated ... excuses after the fact. It's actually reverse logic. 114

In sum, the tendency to discredit women because they are women is deeply embedded in our culture.

People of color, particularly black people, have a similar experience. As many legal scholars have noted, American courts have a long history of discrediting African American witnesses on the basis of their blackness. Such discrediting can occur based on stereotypes that African Americans are less intelligent than are whites, or that they are untrustworthy and dishonest.115 And our culture has a long history of dehumanizing black women and girls, making it less likely that their stories of harm will be believed. Indeed, Oklahoma City police officer Daniel Holtzclaw, who was convicted of twenty-eight counts of stalking, sexual assault, and indecent exposure, appears to have purposefully selected poor black women as his targets because they were less likely

112 See, e.g., Gary Nunn, The Feminisation of Madness is Crazy, GuARdian (Mar. 8, 2012, 9:38 AM), https://www.theguardian.com/media/mind-your-language/2012/mar/08/ mind-your-language-feminisation-madness; Science Diction: The Origin of the Word 'Moon,' NAT'L Pub. Radio: TAlK of The Nation (Jan. 20, 2012, 1:00 PM), https://www.npr.org/2012/01/20/145525014/science-diction-the-origin-of-theword-moon.

113 Nunn, supra note 112.

114 Female Logic, URBAN DictionaRY (Mar. 5, 2008), https://www.urban dictionary.com/define.php?term=female\%20logic.

115 See, e.g., Amanda Carlin, The Courtroom as White Space: Racial Performance as Noncredibility, 63 UCLA L. Rev. 450, 467 (2016); see also Soraya Chemaly, RaGe BeComes HER: THE POWER OF WOMEN's ANGER 8-11 (2018) ("Gender-role expectations ... dictate the degree to which we can use anger effectively in personal contexts and to participate in civic and political life .... A society that does not respect women's anger is one that does not respect women-not as human beings, thinkers, knowers, active participants, or citizens."). 
to be believed.116 Similarly, a juror in the R. Kelly sexual assault trial admitted that he did not credit black women's testimony in the case.117 A 2007 study compared college student assessments of the credibility of a black and a white victim of sexual assault; the black victim was found less believable and more responsible for the harm she suffered.118

Based on all the above, it stands to reason that women who are members of minority groups risk being doubly disbelieved. And available data demonstrates that women of color experience higher levels of harassment than either white women or men of color do.119

Poor people also frequently suffer from targeted disbelief. Emily Martin, Vice President for Workplace Justice at the National Women's Law Center, explains that, in particular, "low-wage and poor women are often not believed when they report instances of sexual harassment.... If you're poor, you may be found less credible when you tell your story." 120 And for poor women, too, expression of emotion related to the experience of harassment likely contributes to credibility discounting. Writers as far back as the late Middle Ages saw peasant expression of anger as reflecting an "instinct opposed to thought." 121 Today, doctors are more likely to dismiss reports of pain presented by women living in poverty as simply being "all in their head." 122 For victims of sexual harassment who live at the intersection of all three of these identities-

116 Maya Finoh \& Jasmine Sankofa, The Legal System Has Failed Black Girls, Women, and Non-Binary Survivors of Violence, ACLU (Jan. 28, 2019, 12:30 PM), https://www.aclu.org/blog/racial-justice/race-and-criminal-justice/legal-system-hasfailed-black-girls-women-and-non.

117 See Jacey Fortin, 'Surviving R. Kelly' Documentary on Lifetime Details Sex Abuse Accusations, N.Y. Times (Jan. 4, 2019), https://www.nytimes.com/2019/01/04/arts/ music/surviving-r-kelly.html.

118 R.A. Donovan, To Blame or Not to Blame: Influence of Race and Observer Sex on Rape Blame Attribution, 22 J. INTERPERSONAL VIOL. 722, 723-24 (2007).

119 Jennifer L. Berdahl \& Celica Moore, Workplace Harassment: Double Jeopardy for Minority Women, 91 J. Applied Psychol. 426, 427 (2006); Jana L. Raver \& Lisa H. Nishii, Once, Twice, Three Times as Harmful? Ethnic Harassment, Gender Harassment, and Generalized Workplace Harassment, 95(2) J. ApPLiEd Psychol. 236, 240-49 (2010); Joan C. Williams, Double Jeopardy? An Empirical Study with Implication for the Debates over Implicit Bias and Intersectionality, 37 HARV. J.L. \& GENDER 185 (2014).

120 Alana Semuels, Low-Wage Workers Aren't Getting Justice for Sexual Harassment, ATLANTIC (Dec. 27, 2017), https://www.theatlantic.com/business/archive/2017/12/ low-wage-workers-sexual-harassment/549158/.

121 Paul Freedman, Peasant Anger in the Late Middle Ages, AnGer's Past: The Social UsES of EMotions IN THE Middle Ages 179 (Barbara H. Rosenwein, ed., 1998).

122 Interview by Gabrielle Levy with Maya Dusenbery, Dying to be Heard, U.S. NEws, (Apr. 20, 2018, 6:00 AM), https://www.usnews.com/news/the-report/articles/201804-20/why-women-struggle-to-get-doctors-to-believe-them. 
those who are poor women of color-these stereotypes feed into each other to further undermine assumptions about their trustworthiness. ${ }^{123}$

\section{Credibility Inflation Awarded to Male Perpetrators of SeXual HARASSMENT}

Our credibility economy is a complex one. ${ }^{124}$ Credibility assessments are inherently comparative in nature; there is an "intimate relationship" between the credibility discounts imposed on womenvictims and the credibility inflations accorded to the men who harass them. ${ }^{125}$ The former can only be fully understood and accounted for in the context of the latter. ${ }^{126}$

The relative epistemic authority of the accuser and the accused can be highly significant in sexual harassment cases. Male perpetrators benefit from the positive cultural preconceptions we associate with their gender and that lead us to be far more likely to believe their statements. ${ }^{127}$ In other words, positive prejudice, connected to social identity, provides a substantial-and not necessarily warranted-boost to the credibility of men who abuse women in the workplace. ${ }^{128}$

This comparative lens clarifies how credibility hierarchies can set limits on our collective social imagination. ${ }^{129}$ Jose Medina explores this idea through an analysis of the trial in the novel, To Kill A Mockingbird.130 The story centers on the 1930's criminal trial of Tom Robinson, a black man accused of raping Mayella Ewell, a white woman. The prosecution's

123 Carolyn M. West, Violence Against Women by Intimate Relationship Partners, in SourceBook on Violence Against Women 143, 164-65 (Claire M. Renzetti et al. eds., 2001) (noting African American women are three times as likely as white women to be killed by an intimate partner).

124 The term "credibility economy" derives from MirandA FRICKER, EPISTEMIC INJUSTICE: Power And The Ethics Of Knowing (2007).

125 See Jose Medina, The Relevance of Credibility Excess in a Proportional View of Epistemic Injustice: Differential Epistemic Authority and the Social Imaginary, Soc. EPISTEMOLOGY 15, 18 (2011) ("[B]eing judged credible to some degree is being regarded as more credible than others, less credible than others, and equally credible as others."). 126 See id.

127 See, e.g., KiRwan InSt. for the Study of Race and Ethnicity, Ohio St. Univ., http://kirwaninstitute.osu.edu/ for a compilation of the extensive literature on implicit bias based on gender, race, and numerous other identity-based factors.

128 Audrey Yap, Credibility Excess and the Social Imaginary in Cases of Sexual Assault, 3(4) FEMinisT PHIL. Q. 1, 1-3 (2017). These positive stereotypes are complicated, of course, by other aspects of a man's social location. A hierarchy of credibility arises, for example, from the interplay of gender and race: white women are presumed to be more credible than black men, but white men are presumed more credible than white women. See, e.g., Medina, supra note 125, at 22.

129 Yap, supra note 128.

130 Medina, supra note 125, at 22. 
cross-examination of Tom includes questions about his motive in routinely stopping by Mayella's home, where he helped her with her chores. ${ }^{131}$ Tom explains that he did so because he felt sorry for Mayella. The jurors are unable to credit his explanation because "this sentiment is unintelligible in their social context. Given the social background of presumed black inferiority, it is unimaginable for a black man to feel pity for a white woman."132 Because this aspect of his story is beyond the then-existing social imagination, Tom's entire defense suffers a credibility discount. ${ }^{133}$

How does this translate into the sexual harassment context? The limited set of narratives available in our collective imagination may affect the credibility we afford to men accused of sexual harassment. As Audrey Yap explains, "Just as we might be confused and skeptical if we heard about a mutiny on a ship filled with even-tempered pacifists committed to norms of civil discourse, we might also be confused and skeptical if we hear about a male feminist sexually assaulting a woman."134

Examples of the effects of our limited imagination can be found in cases where male perpetrators with long-standing feminist bona fides engage in sexual harassment. Take comedian Louis C.K., who "was seen as a prophet of nice dudes, a guy who got it." 135 In his 2013 HBO special, for example, C.K. posed the question, "How do women still go out with guys, when you consider that there is no greater threat to women than men?"136 Louis C.K.'s image made it particularly difficult for many fans to believe the accusations, made by five women, that he had engaged in serious sexual misconduct, including forcing them to watch as he took off his clothes and masturbated in front of them. ${ }^{137}$ These women were all younger comedians; a person as well known as Louis C.K. could make or break their careers. And there is no dispute as to whether Louis C.K. used his considerable professional power to commit these acts; the

131 Id.

132 Yap, supra note 128.

133 See, e.g., Medina, supra note 125.

134 Yap, supra note 128 , at 4.

135 Lindsey V. Thompson, Louis C.K. and the Threat of Fake Male Feminists, GLAmour (Nov. 10, 2017), https://www.glamour.com/story/louis-ck-and-the-threat-of-fakemale-feminists. See e.g., Stuart McGurk, The Problem with Fake Male Feminists, GQ (Apr. 5, 2018), https://www.gq-magazine.co.uk/article/the-problem-with-fake-malefeminists.

136 Thompson, supra note 135.

137 Melena Ryzik, Cara Buckley \& Jodi Kantor, Louis C.K. is Accused by 5 Women of Sexual Misconduct, N.Y. Times (Nov. 9, 2017), https://www.nytimes.com/2017/11/09/ arts/television/louis-ck-sexual-misconduct.html. 
comic ultimately admitted the truth of the allegations. ${ }^{138}$ Nonetheless, his fans found it incredibly difficult to accept this reality. ${ }^{139}$

Similar reactions of shock and denial followed sexual harassment allegations against Mad Men creator Matthew Weiner, who wrote an episode about workplace sexual harassment and subsequently was accused of engaging in the same types of behavior in real life. ${ }^{140}$ Limits on our collective imagination also interfere with our ability to accept stories of sexual harassment perpetrated by men who are widely viewed as repositories of the public trust, such as news analysts Matt Lauer and Charlie Rose. ${ }^{141}$

Even more recently, following a 2020 Democratic presidential debate, long-time MSNBC Hardball host Chris Matthews attacked Senator Elizabeth Warren for referencing allegations, made by a former female employee of candidate Michael Bloomberg, that when he learned she was pregnant he told her to "kill it." The woman sued and the caseone of many sexual harassment lawsuits against Bloomberg-settled out of court. Matthews demanded to know whether Warren believed the woman's allegation; Warren said that she did. Matthews exclaimed: "And why would he lie? ... Just to protect himself?" Warren countered by asking why the woman would lie, and Matthews aggressively insisted: "You're confident of your accusation?" Matthews appeared far less upset about the allegation against Bloomberg than he was that "Warren was making such a fuss about [believing] the woman was telling the truth." 142

138 Jackson McHenry, Louis C.K. Releases Statement on Sexual-Misconduct Allegations: “These Stories Are True,” Vulture (Nov. 10, 2017), https://www.vulture.com/2017/11/ louis-c-k-on-sexual-misconduct-claims-stories-are-true.html.

139 Nosheen Iqbal, A Mockery of \#MeToo: The Rush to Rehabilitate Louis CK is Indecent, GUARDIAN (Sept. 2, 2018, 3:00 PM), https://www.theguardian.com/world/2018/ sep/02/too-soon-rehabilitate-louis-ck-mockery-metoo (noting the "crushing disappointment" his fans experienced and how this news left fans "reeling from processing the transformation of Louis CK, champion of women onstage, to Louis C.K., grotesque harasser of women in reality").

140 McGurk, supra note 135.

141 See, e.g., Madhulika Sikka, Goodnight Charlie Rose, PBS Public Editor (Nov. 21, 2017), https://www.pbs.org/publiceditor/blogs/pbs-public-editor/should-he-stay-orshould-he-go/; Amanda Holpuch, Behind Matt Lauer's Lovable Image, the TV Host Was a Divisive Figure, The Guardian (Nov. 29, 2017), https://www.theguardian.com/media/ 2017/nov/29/behind-matt-lauers-loveable-image-the-tv-host-was-a-divisive-figure.

142 Heather Schwedel, Why Would He Lie?, SLATE (Feb. 26, 2020, 3:12 PM), https://slate.com/news-and-politics/2020/02/elizabeth-warren-chris-matthewsmsnbc-debate-interview-bloomberg.html. Another MSNBC host, Chuck Todd, piled on, expressing disappointment that Warren "hasn't gotten over her feelings" about Bloomberg's history of sexual harassment. Media Matters (@mmfa), TwiTTER (Feb. 26, 2020), https://twitter.com/mmfa/status/1232811999937155074?s=20. 
The common result of this systemic disbelief is that it takes allegations from numerous women to tip the credibility scales against such men. ${ }^{143}$ Professor Catharine MacKinnon has kept track of this gender-based credibility economy as it plays out in the context of campus sexual assault. ${ }^{144}$ She notes that, for decades, "it typically took three to four women testifying that they had been violated by the same man in the same way to even begin to make a dent in his denial. That made a woman, for credibility purposes, one-fourth of a person."145

\section{THE IMPACT OF CREDIBILITY DisCOUNTS ON WOMEN SURVIVORS OF WORKPLACE HARASSMENT}

Survivors suffer a wide range of credibility and experiential discounts when they seek protection, fair treatment, and legal relief. They may suffer these discounts because their true stories of sexual harassment do not sound plausible: they are perceived as personally untrustworthy, or the men who abuse them and deny culpability are automatically seen as far more trustworthy sources. All of this bias is made worse by the fact that anti-harassment policies and grievance procedures typically are designed to serve the organization as "litigation defense centers" that create records to demonstrate in court that the employer did everything possible, rather than to actually protect survivors. ${ }^{146}$ Numerous scholars have explained that internal policies and procedures related to harassment are in fact "instruments of risk management and liability avoidance rather than true engines of change." 147 As one group put it, "Existing structures that claim to address sexual harassment are inadequate and are built to protect institutions, not designed to bring justice to victims."148 In other words,

143 Catharine MacKinnon, \#MeToo Has Done What the Law Could Not, N.Y. Times (Feb. 4, 2018), https://www.nytimes.com/2018/02/04/opinion/metoo-law-legalsystem.html.

144 Id.

145 Id.

146 See, e.g., Claire Cain Miller, It's Not Just Fox: Why Women Don't Report Sexual Harassment, N.Y. Times (Apr. 10, 2017) (quoting Anna-Maria Marshall, Professor of Soc., Univ. of Ill.), https://www.nytimes.com/2017/04/10/upshot/its-not-just-fox-whywomen-dont-report-sexual-harassment.html.

147 Kate Webber Nunez, Toxic Cultures Require a Stronger Cure: The Lessons of Fox News for Reforming Sexual Harassment Law, 122 Penn. St. L. Rev. 463, 487 (2018). See, e.g., TRistin K. GREEN, DisCRimination LAUNDERING: The Rise OF ORGaniZATIONAL INNOCENCE AND THE CRisis of Equal OppoRtunity LAW 39 (2017); Elizabeth C. Tippett, Harassment Trainings: A Content Analysis, 39 BerKeley J. EmP. \& LAB. L. 481, 494, 519 (2018).

148500 Women Scientists Leadership, When It Comes to Sexual Harassment, Academia Is Fundamentally Broken, ScI. Am.: VoICES (Aug. 9, 2018) (emphasis omitted), https://blogs.scientificamerican.com/voices/when-it-comes-to-sexual-harassmentacademia-is-fundamentally-broken/. 
"[a]s nice and well-meaning as they may be, your colleagues in HR don't work for you. Management signs their paychecks, and their No. 1 priority is to serve and protect the company." 149

All of this may feel like déjà vu for a survivor of workplace abuse. ${ }^{150}$ Institution-based discounting closely replicates the typical dynamics of the survivor's relationship with her harasser. Perpetrators of workplace harassment, like system actors, often discredit both the plausibility of a victim's story and her trustworthiness as a truth teller. It is all too common for a woman to hear a routine refrain of: "No, that's not what happened"; or "I would never have touched you if you hadn't provoked me"; or "If you hadn't dressed that way, this never would've happened."151

Perpetrators of sexual harassment also often discredit their women targets based on their personal trustworthiness. Such comments tend to sound like: "You always exaggerate"; or "You're hysterical and overemotional"; or "You're crazy; nothing happened"; or "No one would believe you."152 Finally, victims frequently encounter dismissals of the weight or consequences of the abuse: "Why do you always make such a big deal out of everything?"153

149 Claire Zillman \& Erika Fry, HR Is Not Your Friend. Here's Why, ForTunE (Feb. 16, 2018, 6:30 AM), https://fortune.com/2018/02/16/microsoft-hr-problem-metoo/.

150 See Epstein \& Goodman, supra note 11, at 446-47.

151 See, e.g., Kim K.P. Johnson \& Jane Workman, Clothing and Attributions Concerning Sexual Harassment, 21 Home Econ. Res. J. 160 (1992); Dave McNary, Angela Lansbury Says Women Must Accept Some Blame for Sexual Harassment, VARIETY (Nov. 28, 2017, 9:29 AM), https://variety.com/2017/film/news/angela-lansbury-women-blame-sexualharassment-1202624492/; Hashtag Activism in 2014: Tweeting 'Why I Stayed,' NaT'L PuB. RAdio: All Things Considered (Dec. 23, 2014, 4:21 PM), https://www.npr.org/2014/12/ 23/372729058/hashtag-activism-in-2014-tweeting-why-i-stayed [hereinafter Hashtag Activism].

152 As survivor and activist Beverly Gooden explains, such statements are "easy to believe when it's just the two of you." Hashtag Activism, supra note 151; see also Kat Chow, Gaslighting: How a Flicker of Self-Doubt Warps Our Response to Sexual Harassment, NAT'L Pub. Radio (Nov. 25, 2017, 7:00 AM), https://www.npr.org/2017/11/25/565729 334/gaslighting-how-a-flicker-of-self-doubt-warps-our-response-to-sexualharassment;_Alex French \& Maximillian Potter, Nobody Is Going to Believe You, ATLAnTic (Mar. 2019), https://www.theatlantic.com/magazine/archive/2019/03/bryansingers-accusers-speak-out/580462/; Sargam Jain, Sexual Harassment Can Drive You Crazy, Psychol. Today (Nov. 21, 2017), https://www.psychologytoday.com/us/blog/ psychoanalysis-unplugged/201711/sexual-harassment-can-drive-you-crazy; David Kahn, Are You a Victim of Gaslighting? How to Avoid Being Manipulated by an Unethical Leader, LEADX (Aug. 8, 2017), https://leadx.org/articles/avoid-unethical-leaders.

153 See, e.g., Haley Swenson, "That's Just One More Barrier to Coming Forward": A Professor Who Studies Teens and Sexual Violence on the Very Obvious Reason Girls Don't Report These Crimes, SLATE (Sept. 27, 2018, 2:20 PM), https://slate.com/humaninterest/2018/09/why-teenage-girls-dont-report-sexual-assault.html. 
In other words, the credibility discounts human resource officers and others impose on a woman often echo those that the actual harasser imposes. These institutional and personal betrayals operate in a vicious cycle, each compounding the effects of the other. ${ }^{154}$ For a survivor on the receiving end of one credibility discount after another, these experiences coalesce into a single, powerful gut punch. Credibility discounts become a pervasive part of their existence. This experience can cause women to doubt their power to remedy their situations andin more extreme cases-the veracity of their own experiences.

The consequences of such a broad web of credibility discounting include harms related to psychological wellbeing as well as attendant harms related to increased difficulty in accessing protection, fairness, and justice. When a survivor undertakes the considerable personal and professional risk involved in seeking help, she is looking for resources and protection. But she is also hoping for validation of the harm she has endured-in other words, to have her experience credited. As Rebecca Solnit puts it: "To tell a story and have it and the teller recognized and respected is still one of the best methods we have of overcoming trauma." 155

Research provides ample evidence for this proposition. When Judith Herman interviewed twenty-two victims of violent crimes of all sorts on the meaning of justice, her interview subjects named their most important goal as gaining validation or "an acknowledgment of the basic facts of the crime and an acknowledgment of harm."156

154 Platt, Barton \& Freyd describe the experience of institutional betrayal, in the related context of domestic violence, as follows:

[W] hen this same woman seeks assistance from the police, child protective services (CPS), or health care providers, she enters a world in which her agency cannot be taken for granted. She has no personal role with respect to decision-making by police, CPS, or the hospital and so is particularly vulnerable to objectification or betrayal.... When these institutions betray victims of domestic violence, the 'secondary trauma' from this experience can amplify the feelings of helplessness and loss of control elicited by abuse... Betrayal in these situations may be more abstract than the betrayal by an intimate partner. But the violations of promises implied by their standing in the community-the promise to protect, or heal, or provide for children's welfare-are no less devastating than a partner's betrayal

Melissa Platt, Jocelyn Barton \& Jennifer J. Freyd, Domestic Violence: A Betrayal Trauma Perspective, in Violence Against Women in Families and Relationships: Victimization and The Community Response 185, 201-02 (Evan Stark \& Eve S. Buzawa eds., 2009).

155 Rebecca Solnit, Cassandra Among the Creeps, HARPER's MAG. (Oct. 2014), https://harpers.org/archive/2014/10/cassandra-among-the-creeps/.

156 Judith Lewis Herman, Justice from the Victim's Perspective, 11 VIoLENCE AGAINST WOMEN 571, 585 (2005). 
But when women tell their stories of sexual harassment in the workplace, they are routinely met with responses such as: "Are you sure? Maybe you misunderstand the situation"; or "Oh, he's just like that; don't make a big deal about it"; or "Where's your sense of humor? Lighten up"; or "Stop getting offended so easily about everything." 157 Such responses echo the doubts most women are already experiencing; research shows that women often tell themselves the harassment "is not really important"; that "he didn't mean it"; or "I must have encouraged it myself."158 And in a series of interviews about sexual harassment in the legal employment context, women explained that, following their reports of misconduct, their supervisors exposed them to far closer scrutiny and shared negative feedback about purported errors that previously would never have merited discussion. This has a real impact on a woman's belief in herself; as one woman noted: "The errors that were pointed out were so minor. But when you are in the thick of it, you just start to doubt yourself and your work quality."159 Together, such experiences can cause women to question their own memories and even their own realities. ${ }^{160}$

Survivors of harassment are likely to suffer a range of harms when they find that people repeatedly discredit and invalidate their experiences. First, survivors develop "a sense of powerlessness and futility," expressed in statements such as: "I have taken this enormous risk to share my most vulnerable experiences in public-and they can't/won't hear/see me. I can't find the right words to make them help me."161 Second, survivors develop "a sense of personal worthlessness," wondering, when supervisors take little or no action in response to their stories, whether their experiences have worth or merit, whether their

157 See, e.g., Margaret Gardiner, Why Women Don't Report Sexual Harassment, HuFFinGTON Post (July 21, 2016, 4:29 PM), https://www.huffingtonpost.com/margaretgardiner/why-women-dont-report-sex_b_11112996.html; Elise Hu, Why Some

Survivors of Sexual Harassment and Assault Wait to Tell Their Stories, NAT'L Pub. Radio: All Things Considered (Nov. 15, 2017), https://www.npr.org/2017/11/15/564443 807/why-some-survivors-of-sexual-harassment-and-assault-wait-to-tell-their-stories; see also Complaint and Jury Demand at $\$$ 20, Carlson v. Ailes, No. L00501616, 2016 WL 3610107 (N.J. Super. Ct. Law. Div. July 6, 2016).

158 See Fitzgerald, Swan \& Fischer, supra note 40, at 135.

159 RiKLEEN, supra note 11, at 55.

$160 \mathrm{Hu}$, supra note 157.

161 Epstein \& Goodman, supra note 11, at 449; see also Jon Blistein, Louis C.K. Accuser: 'I Will Never Regret Telling the Truth,' Rolling Stone (May 24, 2018), https://www.rollingstone.com/culture/culture-news/louis-c-k-accuser-i-will-neverregret-telling-the-truth-627813/ (an accuser of Louis CK notes that "[s]peaking out feels like standing in front of the world naked under fluorescent lights on a really bad day ..."). 
pain matters, whether they themselves have real value.162 Finally, survivors develop "a sense of self-doubt," as credibility discounting takes effect: "They are twisting my story, casting doubt, maybe I didn't remember it right, maybe it didn't happen as I think it did. I must be crazy." 163

This dynamic is well-illustrated by the 1944 film Gaslight, ${ }^{164}$ in which a man manipulates his wife's routine experiences in a concentrated effort to create opportunities to discredit her and convince her that she is insane. He does this so effectively that she eventually comes to doubt her own perceptions and memory and ultimately accepts his story that she is delusional and mentally unsound. ${ }^{165}$ Perpetrators of harassment inflict such harm on their targets when they express affection on the heels of sexual coercion, deny that certain promises or commitments were ever made, or simply deny that events in question ever took place. Over time, these incidents build

162 Epstein \& Goodman, supra note 11, at 449. See, e.g., Kristen Houghton, The Truth About Sexual Harassment and Why It's Time We Stopped It, Huffington Post (Apr. 13, 2017), https://www.huffingtonpost.com/entry/the-truth-about-sexual-harassmentand-why-its-time_us_58ed3091e4b0ea028d568d98; Nicole Spector, The Hidden Health Effects of Sexual Harassment, NBC News (Oct. 13, 2017), https://www.nbcnews.com/ better/health/hidden-health-effects-sexual-harassment-ncna810416.

163 Epstein \& Goodman, supra note 11, at 449. The National Domestic Violence Hotline website warns survivors of intimate partner abuse to pay attention to this sort of dynamic:

"You're crazy-that never happened."

"Are you sure? You tend to have a bad memory."

"It's all in your head."

Does your partner repeatedly say things like this to you? Do you often start questioning your own perception of reality, even your own sanity, within your relationship? If so, your partner may be using what mental health professionals call "gaslighting."

$\cdots$

Gaslighting typically happens very gradually in a relationship; in fact, the abusive partner's actions may seem harmless at first. Over time, however, these abusive patterns continue and a victim ... can lose all sense of what is actually happening. Then they start relying on the abusive partner more and more to define reality, which creates a very difficult situation to escape.

What is Gaslighting?, NaT'L Domestic Violence Hotline (May 29, 2014), http://www.the hotline.org/2014/05/29/what-is-gaslighting/ [https://perma.cc/64K3-PYTA].

164 The film is based on a 1938 play of the same name, Gas Light. Id.

165 Gaslight (Metro-Goldwyn-Mayer 1944). 
until, like the wife in Gaslight, survivors may come to doubt their own memory, perceptions, and experience. 166

This dynamic is particularly problematic in the workplace harassment context, where those who engage in harassing behavior often have closer professional ties to supervisors responsible for dealing with the problem. People are more likely to accept what might otherwise appear to be a suspicious narrative when the accused is someone whom they view with respect; the accuser-friendly version of what happened conforms with their preexisting view. ${ }^{167}$ This can result in those closer to the top of the workplace hierarchy being "more inclined to take the side of the person accused of wrongful conduct, rather than serv[ing] as a neutral problem-solver."168 Expert Lauren Rikleen adds:

People at the top of an organization develop close relationships with individuals who have demonstrated loyalty. When the rumor mill begins to sound the alarm about inappropriate conduct among a close lieutenant, the natural tendency for the leader is to choose to believe in the person they see each day-someone who comports himself or herself as a trustworthy and loyal employee. ${ }^{169}$

Thus, the potential for gaslighting grows with the power and influence of the perpetrator. ${ }^{170}$ When employers and other system gatekeepers effectively collaborate in the same patterns used by perpetrators of sexual harassment, survivors may be even more likely to doubt their own abilities to perceive reality and understand their own lives.

The sense of institutional gaslighting described above has immediate and serious consequences for survivors: the system itself becomes an impediment to, rather than a conduit toward, protection. First, as previously discussed, credibility discounting may discourage women from continuing to pursue protection, prevention, or other forms of support. Having their claims met with systemic denial and disbelief gives women ample cause to distrust, and then possibly avoid,

166 Darlene Lancer, How to Know if You're a Victim of Gaslighting, PsYcHol. Today (Jan. 13, 2018), https://www.psychologytoday.com/blog/toxic-relationships/201801/howknow-if-youre-victim-gaslighting [https://perma.cc/634M-8CLF].

167 See, e.g., Leah Savion, Clinging to Discredited Beliefs: The Larger Cognitive Story, 9 J. SCHOLARSHIP TEACHING \& LEARNING 81, 87 (2009) ("People tend to over-rely on instances that confirm their beliefs, and accept with ease suspicious information").

168 RIKLEEN, supra note 11, at 95.

169 Id. at 52.

170 HERMAN, supra note 25 , at 8. 
the institutions ostensibly there to help them. ${ }^{171}$ As the EEOC Task Force Report puts it: "If weak sanctions are imposed for bad behavior, employees learn that harassment is tolerated ...."172

Credibility discounts harm women in an abundance of ways-up to and including the supremely destabilizing process of prompting women to question the truth of their own experience. People devalue and gaslight women from every direction, discouraging them from continuing to seek systemic support. Ripple effects discourage the broader community of women from seeking the help they need. And our entire society suffers from the failure to fully understand, credit, and value a substantial part of the human experience. Together, these harms work to form a formidable obstacle to women's healing, safety, and ability to obtain justice.

\section{MOVInG ForWARD: InITIAL STEPS TOWARD ERADICATING GENDER-BASED CREDIBILITY DiSCOUNTING IN THE WORKPLACE HARASSMENT CONTEXT}

As the previous discussion demonstrates, credibility discounting inflicts deep and pervasive harm on women who experience workplace harassment. How can we change our response to female victims to eradicate the gauntlet of doubt and disbelief they face in their efforts to obtain protection, healing, and justice?

Some forms of credibility discounting may be responsive to fairly straightforward interventions-particularly those rooted in listeners' failure to understand a woman's experience of sexual harassment on the job. ${ }^{173}$ The best way to cure knowledge gaps among system gatekeepers about the effects of psychological trauma on information processing and memory, about the ways that trauma can affect witness demeanor, and about the ways survivors act in the aftermath of harassment is, of course, to work on improving understanding. Intensive training could, at least in theory, allow managers, human resource officers, union representatives, and judges to better understand these correlates of the

171 Institutional betrayal occurs when an institution causes harm to an individual who trusts or depends upon that institution. Carly Parnitzke Smith \& Jennifer J. Freyd, Institutional Betrayal, 69 Am. PsychoL. 575, 575 (2014). Researcher Rebecca Campbell described the secondary victimization of women seeking legal services in the aftermath of interpersonal violence and found that when survivors reach out for help, often at a time of great vulnerability and need, "they place a great deal of trust in the legal, medical, and mental health systems as they risk disbelief, blame, and refusals of help." Rebecca Campbell, The Psychological Impact of Rape Victims' Experiences with the Legal, Medical, and Mental Health Systems, 63 AM. PsychOL. 702, 703 (2008); see also Heidi Grasswick, Epistemic Injustice in Science, in RoutLEDGe HANDBOok, supra note 68, at 313; Platt et al., supra note 154, at 201-02.

172 EEOC TASK FORCE REPORT, supra note 3, at 34.

173 Epstein \& Goodman, supra note 11, at 453. 
harassment experience. But training can only be effective if those receiving it are genuinely open and committed to absorbing new understanding. ${ }^{174}$ For those who lack this commitment, training alone is unlikely to be enough.

And other forms of credibility discounting described aboveparticularly those rooted in negative stereotypes and bias-are more resistant to change and may require a more complex set of interventions. The cultural assumption that an outsized concern for financial gain tends to improperly motivate women, and the related assumption that women simply lack full capacity as truth tellers, are deeply embedded in our society. ${ }^{175}$

Remedying our societal tendency to discount the credibility of women will not be easy; it will require motivation, awareness, and effort. Each of us, in our role as listener, must take responsibility to intentionally and consciously shift our assumptions. In Fricker's words, the listener must adopt "an alertness or sensitivity to the possibility that the difficulty one's [witness] is having as she tries to render something communicatively intelligible is due not to its being nonsense or her being a fool, but rather to some sort of gap in [the existing interpretive] resources." 176

174 This conclusion is based on my own extensive experience in conducting trainings with judges, police officers, and prosecutors in the field of intimate partner violence, as well as numerous conversations with other trainers in that field.

175 See supra text accompanying notes 83-124. A central challenge here is that many system gatekeepers are unaware of the gender-based stereotypes that are, in fact, shaping their perceptions and decisions. See generally InT'L LABOR ORG.: ACT/EMP, BREAKING BARRIERS: UnCONSCIOUS GENDER BIAS IN THE WORKPLACE, (Aug. 2018) https://www.ilo.org/wcmsp5/ groups/public/---ed_dialogue/---act_emp/documents/publication/wcms_601276.pdf. As long as these biases remain unconscious, change is unlikely. Psychologists interested in challenging unconscious prejudicial perceptions, also called "implicit biases," have shown that participants who develop both a strong negative attitude toward prejudice and a strong belief that they themselves are indeed prejudiced are able to reduce the manifestations of their implicit bias. Jack Glaser \& Eric D. Knowles, Implicit Motivation to Control Prejudice, 44 J. ExPERIMENTAL Soc. Psychol. 164, 164 (2008). One of the most prominent and wellresearched approaches to bias reduction is called the "prejudice habit-breaking intervention." Patricia G. Devine et al., Long-Term Reduction in Implicit Race Bias: A Prejudice Habit-Breaking Intervention, 48 J. EXPERIMENTAL Soc. PsYCHOL. 1267, 1267 (2012). Once participants achieve awareness of their own biases and of the damage such biases can cause, they use cognitive strategies to accomplish behavioral change, such as stereotype replacement, perspective taking, and counter-stereotypic imaging. Id. at 1270 . One notable study based on such strategies demonstrated that habit-breaking interventions produced long-term changes in key outcomes related to implicit racial bias, increased concern about discrimination, and greater reported beliefs that there could be bias present in participants' thoughts, feelings, and behaviors. Id. at 1277 . These changes endured two months following the intervention. $I d$.

176 FRICKER, supra note 124, at 169. 
The crucial first step is to shift away from an automatic, uninformed disbelief of women's stories-to begin, in other words, to distrust one's own distrust. Philosopher Karen Jones proposes the imposition of a "self-distrust rule": gatekeepers should allow "the presumption against ... believing an apparently untrustworthy witness [to] be rebutted when it is reasonable to distrust one's own distrust or [one's own] judgments of implausibility." 177

Of course, in distrusting one's instincts to distrust a survivor, system actors should not go to the other extreme and automatically credit all survivor stories. Instead, they need only resist the reflexive presumption against crediting women's stories, make an effort to overcome hermeneutic gaps, and open their minds to accepting a broader range of stories and storytellers. Philosopher Jose Medina calls this process one of cultivating a capacity for "virtuous listening."178

Workplace gatekeepers and judges can engineer this openness into their traditional approaches to assessing credibility. Contributing factors such as the internal and external consistency of story, as well as storyteller or witness demeanor, can easily expand to accommodate new understandings. For example, a human resource officer who notices temporal gaps in a woman's story can resist the urge to automatically discount her credibility. Instead, the officer might ask follow-up questions to obtain information about the impact of trauma on the witness. For example:

- Are you able to remember the full story of what happened, from beginning to end?

- It's fine if you can't tell me what happened in complete detail; just tell me any specific part of this experience that you do remember.

- How would you describe your ability to remember what happened here? Do you remember some pieces, like visual images, smells, sounds, or anything like that? Tell me about those.

A gatekeeper listening to a woman describe her experience of abuse with either a flat affect or a tone overwhelmed with hysteria or fury might ask:

- I notice you seem completely calm right now. Does that reflect how you felt at the time of the events you're describing?

177 Karen Jones, The Politics of Credibility, in A Mind OF ONE's OWn: FEMINIST EsSAYS ON REASON AND Objectivity 154, 164 (Louise M. Antony \& Charlotte E. Witt eds., 2002).

178 JoSE MEDINA, Varieties of Hermeneutical Injustice, in RoUTLEDGE HANDBOOK, supra note 68, at 26. 
- (If not): What do you think explains the difference?

or:

- I notice you seem extremely upset/angry right now. Can you help me understand what you're feeling, and why?

To help counter the more general tendency to discredit women as women, a [listener] might take the issue on directly:

One of the most basic things a [manager/human resource officer/judge] has to do is to decide whose story to believe. In this case, like so many others, each of you may end up telling me a different story. Can you help me see the reasons I should credit, or believe, your side of the story, as well as the reasons I should not credit the story told by the other [person involved]? ?19 $^{179}$

In the end, the listener may find a woman personally untrustworthy or dismiss her story as implausible. But by engaging in a systematic reorientation of their beliefs, gatekeepers can begin to reverse unfair and automatic presumptions of distrust and thus avoid inflicting testimonial and hermeneutic injustice.

Recent technological innovations have created reporting methods designed to reduce both the risk and the discounting associated with inperson reporting. Phone-based apps-such as Callisto and JDoe-now allow a woman to make an online, encrypted, and time-stamped report that she can either submit directly to workplace authorities or can keep on hold until she is ready to do so. ${ }^{180}$ Perhaps most importantly, she has the option to keep it in a reporting escrow, where it will remain, uninvestigated, until another misconduct allegation is made against the same perpetrator. ${ }^{181}$ This feature allows women to make timely reports without risking the credibility discounting associated with being the first to do so. ${ }^{182}$

179 The examples above are taken from Epstein \& Goodman, supra note 11, at 455

180 See, e. g., How Smartphone Apps Could Change the Way Sexual Assault is Reported, NAt'l Pub. RAdio: All Things Considered (Aug. 21, 2018), https://www.npr.org/2018/ 08/21/637122361/how-smartphone-apps-could-change-the-way-sexual-assault-isreported.

181 See, e.g., Ian Ayres, Meet Callisto, the Tinder-Like Platform that Aims to Fight Sexual Assault, WASH. PosT (Oct. 9, 2015), https://www.washingtonpost.com/opinions/usinggame-theory-technology-to-fight-sexual-assault/2015/10/09/f8ebd44e-6e02-11e5aa5b-f78a98956699_story.html.

182 Id. 
Together, these initial reforms could have a substantial individual and institutional impact, with a concomitant diminution in discounting women's credibility. But, as noted above, two prerequisite conditionswhether in reducing the "willful interpretive gap" in understanding women's experiences, in eradicating cultural stereotypes of women as inherently untrustworthy, or in taking women's experiences seriously-are the acknowledgment of gender-based bias and the will to change.

\section{CONCLUSION}

Progress is possible. The \#MeToo movement represents the beginning of a shift in cultural understanding and goodwill. The floodgate of stories from blue-collar workers to Hollywood A-listers has forced society to face the realities encountered by so many women in the American workplace. It is time to build on the momentum of this new awareness and take concrete steps to implement meaningful reform in the employment and justice systems. As Rebecca Solnit explains:

If the right to speak, if having credibility, if being heard is a kind of wealth, that wealth is now being redistributed. There has long been an elite with audibility and credibility, and an underclass of the voiceless.

As the wealth is redistributed, the stunned incomprehension of the elites erupts over and over again, a fury and disbelief that this woman ... dared to speak up, that people deigned to believe her, that her voice counts for something, that her truth may end a powerful man's reign. These voices, heard, upend power relations. ${ }^{183}$

183 Rebecca Solnit, Silence and Women's Powerlessness Go Hand in Hand-Women's Voices Must Be Heard, GUARDIAN (Mar. 8, 2017), https://www.theguardian.com/ commentisfree/2017/mar/08/silence-powerlessness-womens-voices-rebecca-solnit. 